\title{
Quantitative Sourcing of Slackwater Deposits at Boila Rockshelter: A Record of Lateglacial Flooding and Paleolithic Settlement in the Pindus Mountains, Northwest Greece
}

\author{
J.C. Woodward, ${ }^{1}$ R.H.B. Hamlin, ${ }^{1}$ M.G. Macklin, ${ }^{2}$ P. Karkanas, ${ }^{3}$ \\ and E. Kotjabopoulou ${ }^{3}$ \\ ${ }^{1}$ School of Geography, University of Leeds, Leeds, LS2 9JT, United Kingdom \\ ${ }^{2}$ Institute of Geography and Earth Sciences, University of Wales, Aberystwyth, \\ SY23 3DB, United Kingdom \\ ${ }^{3}$ Ephoreia of Palaeoanthropology-Speleology, Ardittou 34B, 11636 Athens, \\ Greece
}

\begin{abstract}
Evidence for large floods in the Pindus Mountains of Northwest Greece during the Lateglacial period is provided by a sequence of fine-grained slackwater sediments preserved beneath the Late Upper Paleolithic deposits at Boila rockshelter in the Voidomatis River basin. We have applied a quantitative sediment fingerprinting approach to estimate the relative contributions from different catchment sediment sources to these flood sediments. Our approach utilizes recent developments in hydrology and fluvial geomorphology where researchers have used sediment properties to establish the source of suspended sediments transported in rivers during present-day flood events. The data set used to create the composite sediment source fingerprint comprised nine tracer properties including eight trace elements (determined by X-ray fluorescence techniques) and magnetic susceptibility. The Boila sequence has been dated by conventional and AMS radiocarbon techniques, and the central and upper part of the flood sediments were deposited between ca. 14,310 \pm 200 and 13,960 \pm 260 radiocarbon yr B.P. These flood events took place during the global cooling associated with Heinrich event 1 , although the sediment fingerprinting data indicate that glacial activity in the Voidomatis basin was no longer supplying large volumes of sediment to the fluvial system at this time. The slackwater deposits are mainly derived from flysch sediments and soils from nonglaciated parts of the Voidomatis River basin. The results of this approach compare well with lithological estimates based on micromorphological analyses and are in good agreement with existing data on the Late Pleistocene and Holocene behavior of this river system. The slackwater sediments offer important insights into the nature of the river environment and the wider catchment system during the Lateglacial period when the Klithi rockshelter (ca. $2 \mathrm{~km}$ upstream of Boila) was the focus of Paleolithic activity in the Voidomatis Gorge. In appropriate depositional contexts, quantitative sediment fingerprinting constitutes a valuable geoarchaeological tool for the investigation of rockshelter and cave sediment records that can improve our understanding of site formation processes and their broader environmental context. This approach is a valuable complement to the micromorphological investigation of rockshelter sediment records. (C) 2001 John Wiley \& Sons, Inc.
\end{abstract}




\section{INTRODUCTION}

Fine-grained sediment particles (sands, silts, and clays) can be transported to rockshelter and cave environments from a variety of sources by a wide range of geomorphological processes, including colluvial, fluvial, and eolian action (see Goldberg, 1992; Woodward and Bailey, 2000). The type and relative importance of the fine sediment sources involved will change over time as landscape processes and vegetation dynamics within the catchment area of the site are influenced by climate change and other factors (see Courty and Vallverdu, this issue). Thus, the fine sediment component within rockshelter and cave sediment sequences that is derived from off-site (allogenic) sources may form an important record of local and regional environmental change (Woodward, 1997a). Establishing the source of the fine sediments in such records allows these sequences to be placed within their wider geomorphological and stratigraphic context, which is essential to achieve a fuller understanding of site formation processes. At the same time, because rockshelters can protect and store their deposits for long periods of time, the allogenic fine sediment component may record information on geomorphological events and sediment fluxes that has not been preserved in the wider environment (Woodward and Bailey, 2000; Courty and Vallverdu, this issue).

In most rockshelter sites, the coarse fraction of the sedimentary fill is dominated by the products of host rock breakdown. This material can be produced by a variety of processes that detach particles from the limestone shelter walls and ceiling or from the cliff face above the site. Coarse sediments (including non-limestone lithologies) can also be introduced by fluvial processes, mass movements, and other mechanisms (including human activity), but local sources are usually dominant. The fine sediment fraction commonly forms a matrix within these coarse-grained sedimentary units or comprises distinctive, exclusively fine-grained sedimentary units. Whatever their depositional or stratigraphic context, information on the source of the fine sediments can provide valuable paleoenvironmental information (e.g., Mandel and Simmons, 1997; Woodward, 1997b; Courty and Vallverdu, this issue). To date, however, studies incorporating data on the provenance of rockshelter sediments have commonly involved only qualitative or semiquantitative estimates of sediment source components based on lithological or mineralogical analyses (Farrand, 1975; Woodward, 1997b), particle size characteristics (Woodward, 1997a), or micromorphological observations (Goldberg, 1992; Karkanas, 1999).

Cornwall (1958) was one of the first researchers to recognize the value of establishing the origin of cave and rockshelter sediments as a means of elucidating site formation processes. He pointed out that sediment properties could be used to fingerprint sediment source and identify the delivery mechanisms involved. In a discussion of the various processes that may contribute to the deposition of fine sediments within caves and rockshelters, Cornwall (1958:31) observed:

Mineralogical, physical, and chemical investigations could undoubtedly resolve some of the more puzzling questions about the origins of cave-earths and assign to a particular deposit the appropriate proportions in which these agencies have contributed to its formation. 
To this end, this paper makes use of recent conceptual and methodological developments in hydrology and fluvial geomorphology where researchers have evaluated a range of approaches and sediment properties to establish the source of suspended sediments transported in rivers during present-day flood events (see Walling and Woodward, 1992; Walling et al., 1993; Walling and Woodward, 1995; Collins et al., 1997). We have used a quantitative sediment fingerprinting approach (see Walling et al., 1993) to establish the source of fine-grained alluvial slackwater sediments of Lateglacial age preserved in the rockshelter site of Boila in the Voidomatis River basin of Northwest Greece (see Kotjabopoulou et al., 1997; Kotjabopoulou et al., 1999). This paper describes the methods employed in sediment source identification and discusses the implications of the results for our understanding of Late Pleistocene river behavior and Late Upper Paleolithic settlement in the area. More generally, we also aim to show that this approach can provide a valuable complement to the micromorphological investigation of sedimentary sequences and, in appropriate contexts, where diagenesis has not been severe, that quantitative sediment fingerprinting constitutes a valuable geoarchaeological tool for the investigation of site formation processes in rockshelters and caves (see Woodward and Bailey, 2000; Hamlin et al., 2000).

\section{BOILA ROCKSHELTER IN THE PINDUS MOUNTAINS, NW GREECE}

\section{Geomorphological Setting}

Boila rockshelter (ca. $410 \mathrm{~m}$ above sea level) is located in the lower reaches of the Voidomatis River in the Pindus Mountains of Northwest Greece (Figure 1) approximately $2 \mathrm{~km}$ downstream of the Late Upper Paleolithic site of Klithi (Bailey, 1997a). The site lies immediately upstream of the point where the river emerges from the confines of the Lower Vikos Gorge onto the Konitsa basin (Figure 2). It is a small rockshelter with a shallow overhang in Eocene limestone, although the presence of large boulders on the talus slope beneath the site and in the Pleistocene river gravels below indicates that the overhang extended further outward in the past and has been subject to more than one episode of collapse (see Kotjabopoulou et al., 1997). At present, the floor of the rockshelter lies approximately $11 \mathrm{~m}$ above the bed of the modern river channel and the base of the talus slope beneath the site lies about $20 \mathrm{~m}$ away from the river. The shelter opening is $17 \mathrm{~m}$ wide, and the present floor covers an area of ca. $80 \mathrm{~m}^{2}$.

\section{Excavations and Stratigraphy}

The archaeological excavations at Boila began in 1993 under the direction of Eleni Kotjabopoulou of the Ephoreia of Palaeoanthropology-Speleology in Athens. The excavations extended over an area of ca. $13 \mathrm{~m}^{2}$ and $8 \mathrm{~m}^{3}$ of deposit have been removed from the site (Figure 3). Compared to other excavated sites in Epirus, the deposits containing archaeological materials are relatively shallow, attaining an average thickness of approximately $80 \mathrm{~cm}$. Boila contains a Late Upper Paleolithic sequence, and nine radiocarbon ages indicate that Paleolithic occupation took 


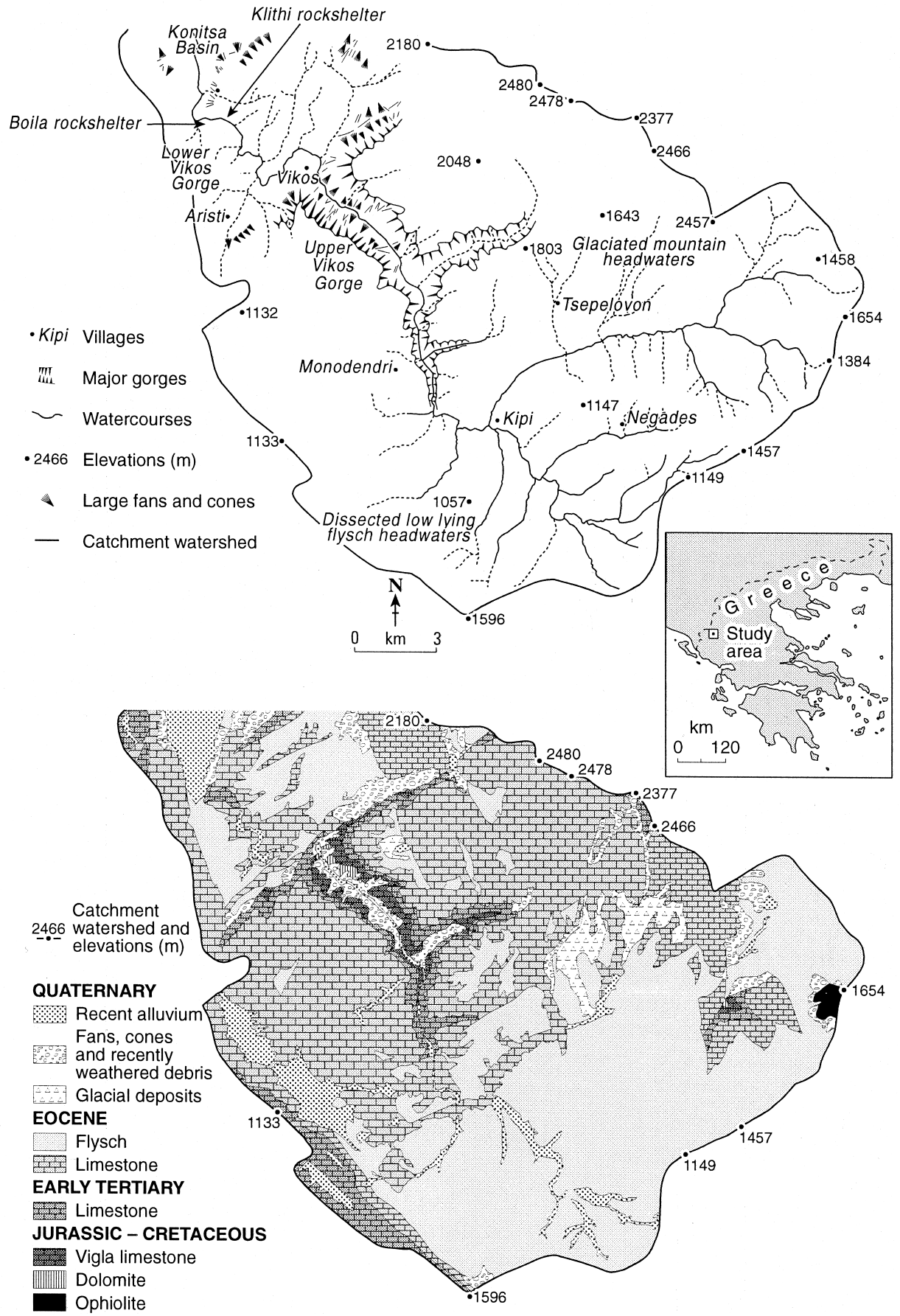


place between ca. 14,000 and 10,000 yr B.P. The faunal record is dominated by chamois, ibex, and red deer, and the lithic assemblage includes bladelets, burins, and endscrapers produced mainly from local flints obtained from the Voidomatis River gravels (Kotjabopoulou et al., 1999). The main period of occupation at Klithi is earlier in the Lateglacial period and well bracketed between about 16,500 and 13,500 yr B.P. (Bailey and Woodward, 1997).

Detailed information on the Quaternary fluvial sediments and landforms of the wider Voidomatis basin and their paleoenvironmental significance can be found in Macklin et al. (1997) and Hamlin et al. (2000). The stratigraphic relationships between the fluvial sediments in the Boila sequence are shown schematically in Figure 4(A). Significantly, the entire site, and all of the archaeological sequence, overlies well-rounded, coarse-grained, limestone-rich Late Pleistocene alluvial gravels (see Lewin et al., 1991). Uranium-series determinations on calcite cements formed within these coarse-grained sediments in the vicinity of the rockshelter have yielded ages of 25,000 \pm 2000 and 24,000 $\pm 2000 \mathrm{yr}$ B.P. (see Hamlin et al., 2000). These sediments are overlain by a series of well-preserved fine-grained slackwater sediments (see Baker et al., 1983; Kochel and Baker, 1988) that attain a maximum thickness of ca. $60-70 \mathrm{~cm}$. In view of this stratigraphy, and the proximity of the rockshelter to the modern river channel, Kotjabopoulou et al. (1997) have pointed out that the site offers an opportunity to examine in greater detail the chronological and stratigraphical relationships between the Late Upper Paleolithic archaeological sequence and the fluvial history of the Voidomatis valley at the end of the last cold stage (see Macklin et al., 1997; Hamlin et al., 2000).

\section{The Slackwater Deposits at Boila Rockshelter}

Slackwater sediments are fine-grained alluvial deposits that have settled out of suspension during flood events in zones of reduced flow velocity. They are commonly well preserved in tributary ravines, in rockshelters and caves, and downstream of bedrock obstructions in narrow gorges (e.g., Baker et al., 1983; Kochel and Baker, 1988). In favorable settings, thick slackwater sequences can accumulate, and they have been used to reconstruct long-term flood histories (see Ely and Baker, 1985; O'Conner et al., 1994), yet the provenance of these deposits has received relatively little attention. Slackwater sediments have not been widely reported in the Mediterranean region, although they are present at a number of locations in the Voidomatis River basin (see Lewin et al., 1991; Hamlin, 2000).

Figure 1. Maps of the Voidomatis River basin in NW Greece. The upper map shows the drainage network and the five major physiographic areas described by Lewin et al. (1991) and Bailey et al. (1997). The location of the Boila and Klithi rockshelters in the Lower Vikos Gorge is also shown (see Figure 2). The lower map is a detailed geological map of the Voidomatis River basin (after IGME, 1968, 1970) showing the spatial extent of many of the potential sediment sources listed in Table II. The Quaternary sediments and landforms are not shown in detail on this map. 

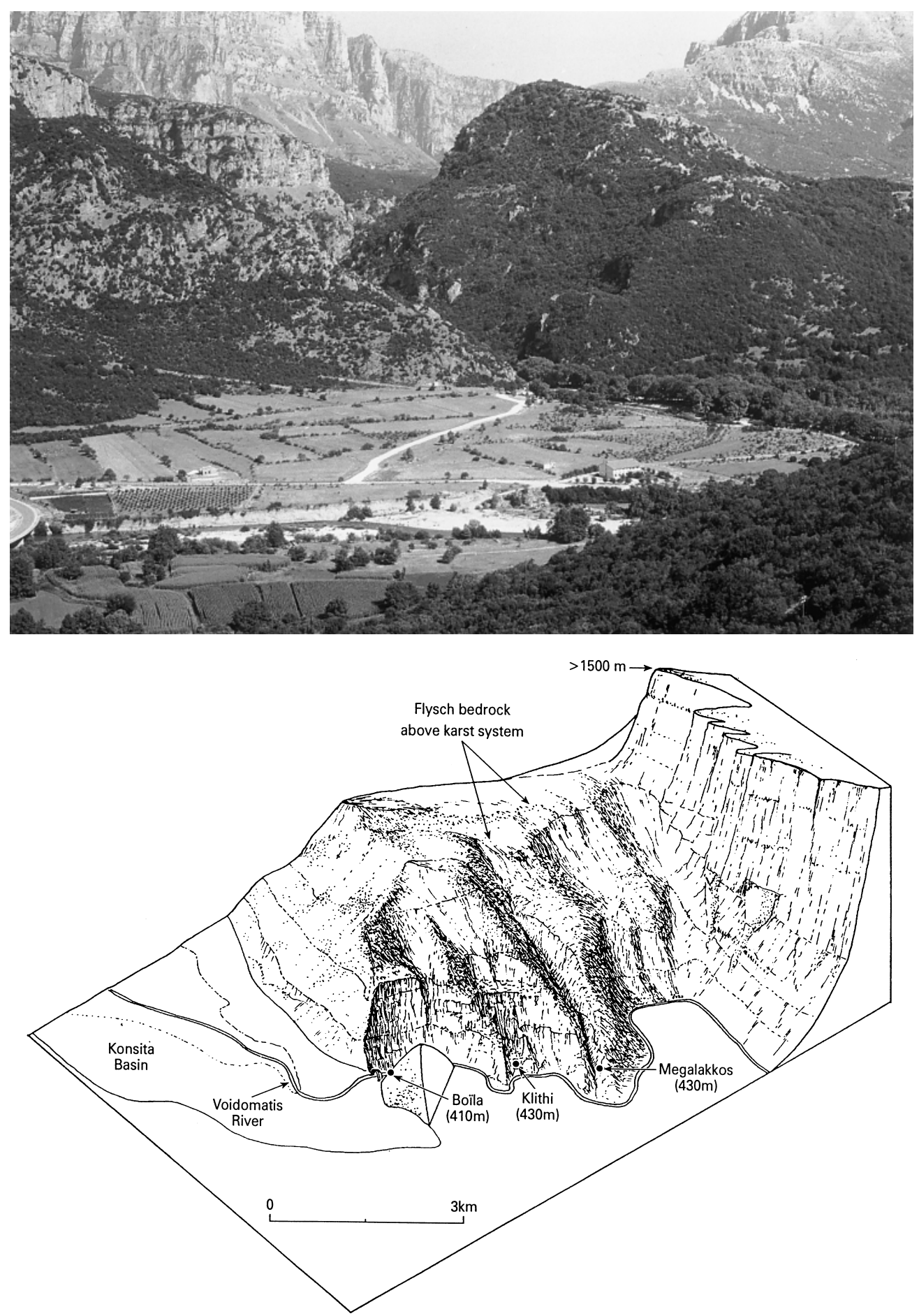


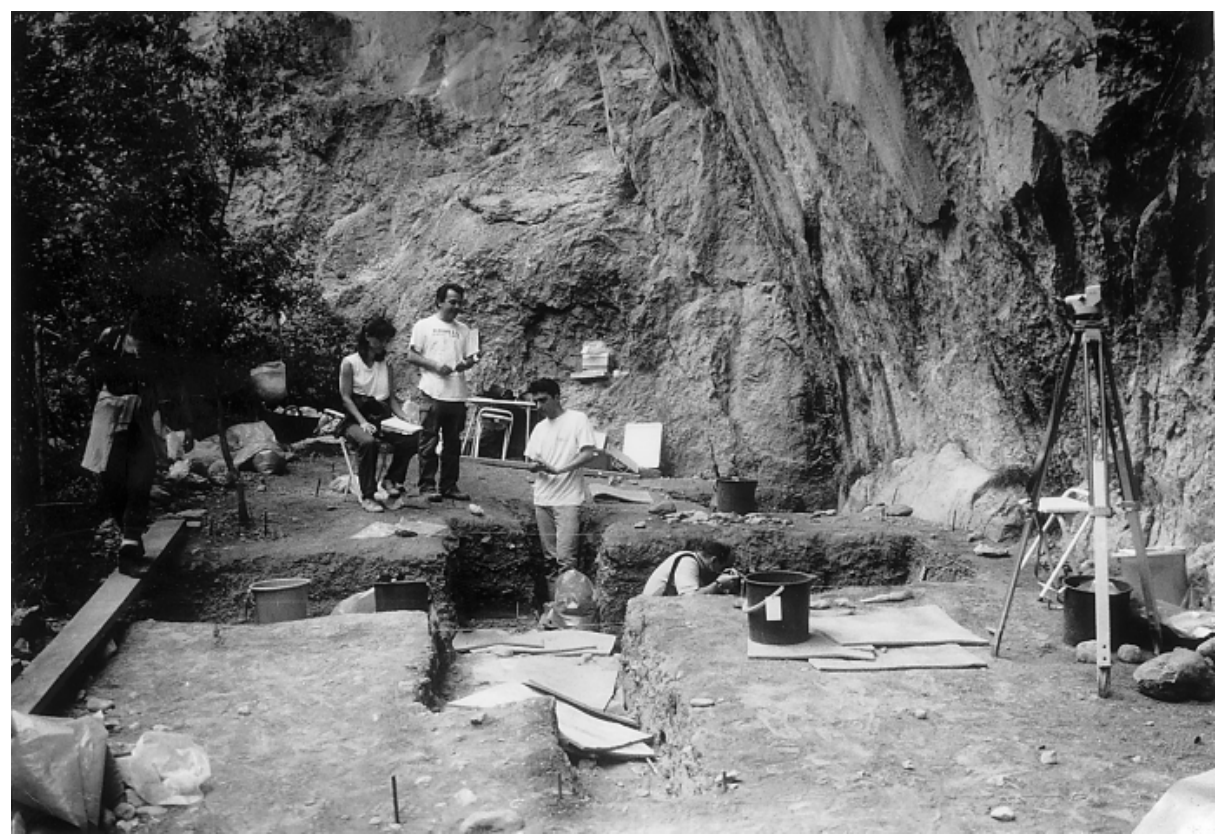

Figure 3. Excavations at Boila in July 1997. View looking to the south (upstream).

Sedimentological analysis of the entire Boila sequence using micromorphological analysis and other techniques is being carried out by Dr. Panagiotis Karkanas, and a full site report will be published elsewhere. This paper focuses primarily on the slackwater sediments (Figure 4) and, in particular, on their stratigraphy, sedimentology, provenance, and paleoenvironmental significance in relation to Late Upper Paleolithic settlement in the basin. The microstratigraphy of these deposits has been investigated from thin sections cut from resin-impregnated blocks of sediment (Figure 4[A]) (see Courty et al., 1991; Karkanas, 2001). As part of the micromorphological investigation of the rockshelter sequence, the alluvial sediments that

Figure 2. Photograph showing the southern part of the Konitsa Basin immediately downstream of the Boila rockshelter and looking upstream into the Lower Vikos Gorge. Boila is located approximately 11 $m$ above the left bank of the modern Voidomatis River channel at the end of the Voidomatis (Lower Vikos) Gorge. The lower figure shows the Lower Vikos Gorge in the Voidomatis River basin and the Late Upper Paleolithic rockshelter sites of Boila, Klithi, and Megalakkos (based on Gowlett et al., 1997). Although the major flysch basins are located in the catchment headwaters upstream of Kipi (Figure 1), flysch rocks and soils are also present above the limestone formations on either side of the Lower Vikos Gorge. 


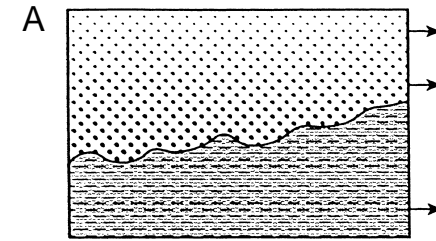

Fine sand

Charcoal fragments dated to $14,310 \pm 200{ }^{14} \mathrm{C}$ Years BP and fine sand

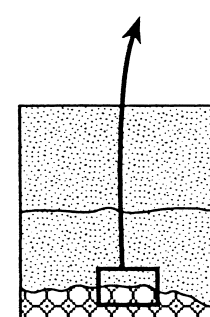

$\infty \times$ 1000 10.80 808080 0.8 100000 $\times 1000$ 100

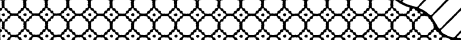
\& 1.10 800000 (1)

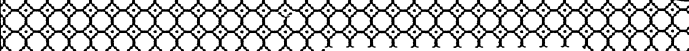
0.80 $\infty \times 10 \%$

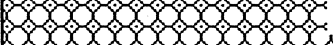
Late Pleistocene

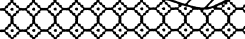
river gravels

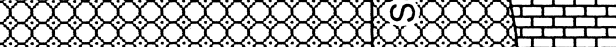

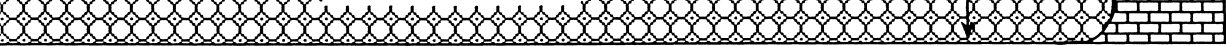

B

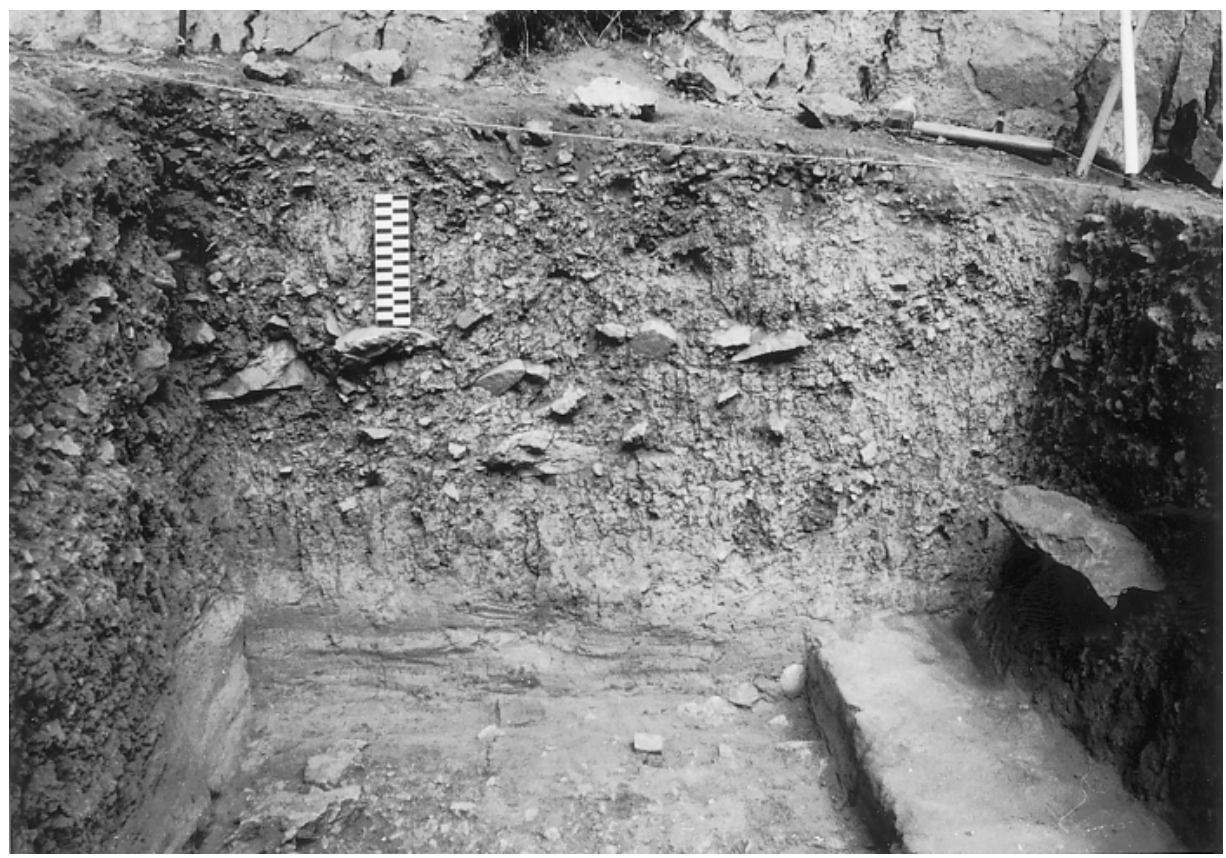


have not yielded archaeological materials have been subdivided into Sequence A and Sequence B. Sequence A comprises the upper part of the Late Pleistocene gravels and the lower (weathered) section of the slackwater sediments (Figure 4[A]). Sequence B comprises the central part of the slackwater sediments below the upper flood sediments that have yielded Late Upper Paleolithic materials (Figure 4[A]). Micromorphological data from Sequence B (thin sections 33a to 33e; see Figure $4[\mathrm{~A}])$ are presented below. The lower part of the slackwater sequence consists of brownish, weathered alluvial sediments that are laterally enriched in angular limestone fragments derived from the erosion of the rockshelter walls. The gradational contact between the upper part of the fine-grained slackwater sediments and the overlying deposits consisting of coarse angular limestone clasts is shown in Figure 4B.

A $1.5 \mathrm{~m}$ section exposed in the rear of the shelter was logged and sampled in detail in the summer of 1997 as part of a wider study of Quaternary river behavior and catastrophic flooding in Mediterranean mountain environments (Macklin et al., 1998; Hamlin et al., 2000). The slackwater sediments were logged in detail, and samples were taken for laboratory analysis. Ten of these samples were large enough to be used for quantitative sediment source fingerprinting; this set included a sample from the fine matrix within the Late Pleistocene gravels at the base of the sequence (see Woodward et al., 1992; Hamlin et al., 2000). These samples span the full slackwater sequence and are marked with an asterisk in Figure 5.

The slackwater sequence has been grouped into five alluvial units on the basis of macrostratigraphic features such as marked textural changes, scour surfaces, discrete layers of scree separating units, and weathering features. These field observations were supplemented by particle size and magnetic susceptibility data (Hamlin, 2000). Alluvial Unit 1 is capped by a thin band of scree and represents the upper part of Sequence A described above. The contact between alluvial units 2 and 3 is undulating; together these units represent Sequence B (Figure 4A). The sediments of alluvial Unit 3 have the lowest sand content in the slackwater sequence (Hamlin, 2000). The overlying sediments of alluvial Unit 4 are much finer than those of alluvial Unit 5, which have the highest sand content and limestone component of the slackwater sequence.

Figure 4. (A) Schematic section (not to scale) of the alluvial stratigraphy at Boila rockshelter beneath the sediments dominated by coarse angular limestone clasts produced by erosion of the shelter walls. The stratigraphic context of the micromorphological data (thin sections 33a-33e) presented in this paper is also shown. (B) Photograph of part of the slackwater sediments exposed during excavations at Boila in July 1997. The angular, coarse-grained sediments (éboulis) above the fine-grained alluvial units contain the bulk of the faunal and lithic materials recovered from excavation. Scale bar in centimeters. Micromorphological data indicate that the upper alluvial units (4 and 5) show some evidence of weathering. They have also been disturbed by postdepositional human activity and contain low concentrations of Late Upper Paleolithic material. 


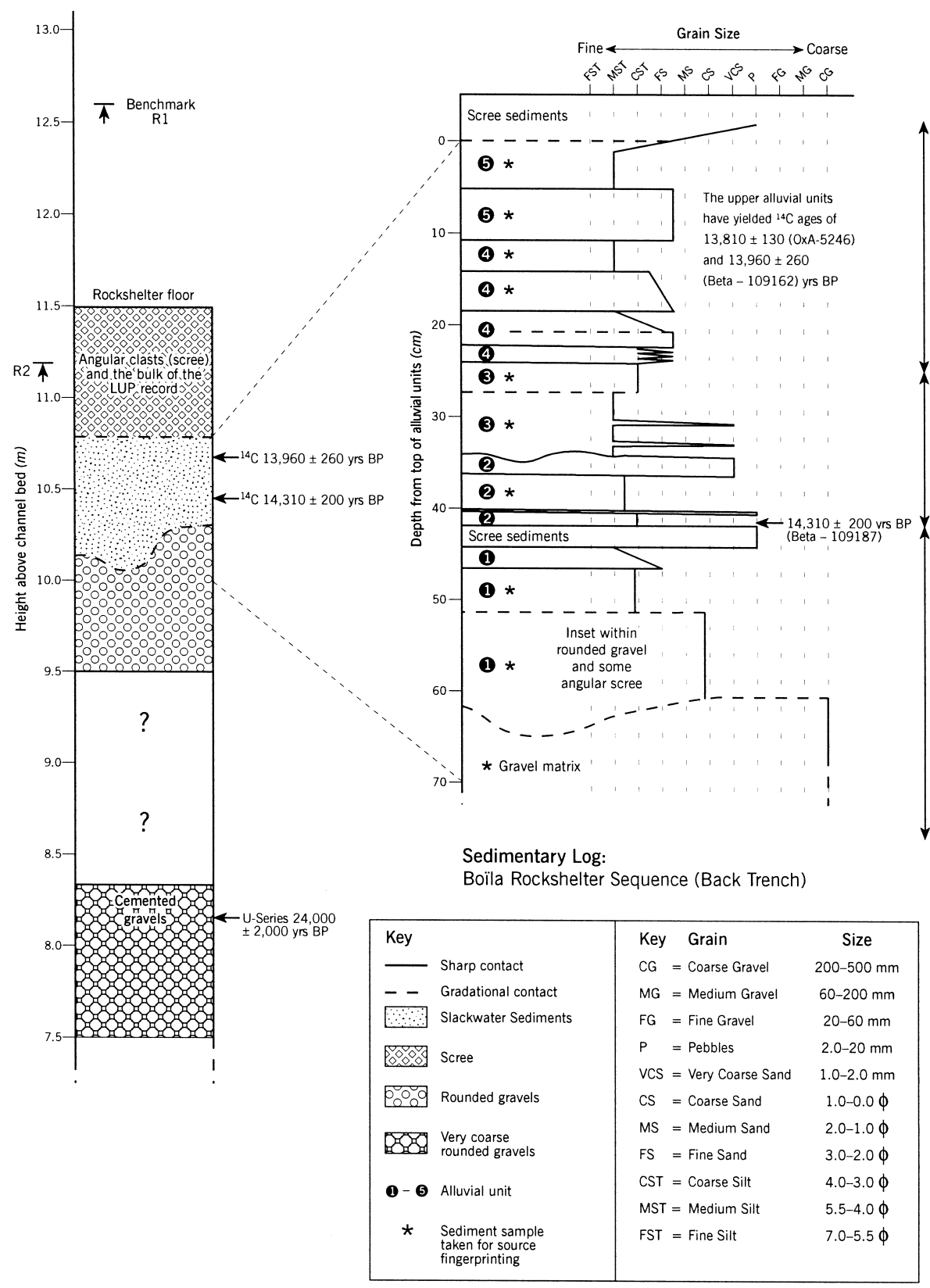

Figure 5. (A) Sediment logs of the slackwater sediments at Boila and Late Pleistocene alluvial sediments on the valley floor in the vicinity of the rockshelter. The slackwater sediments have been grouped into a series of alluvial units (1-5). See text for explanation (modified after Hamlin et al. [2000]). 


\section{Microstratigraphy of Sequence B}

The results of micromorphological analysis of Sequence B are shown in Figure 6 and Table I. These highlight the potential complexity of slackwater sediment sequences and the value of a micromorphological approach for elucidating stratigraphic features that are not discernable from field observations. Sequence B includes a series of scour surfaces representing erosional contacts, graded sequences of various thicknesses, and microscale couplets and laminae (Table I and Figure 7). Flysch-derived silt and clay particles dominate the fine laminae (commonly 1$2 \mathrm{~mm}$ thick), and fine sands are an important component of the lower part of couplets. Bedding features such as current ripples, microscopic cross-stratification, and preferred particle orientation are evident, although many of these are laterally variable. The contact between the weathered sediments of Sequence A and the overlying sediments of Sequence B is shown in Figures 6 and 7(B). There is also some evidence for bioturbation above and below this contact. Three samples were collected from Sequence B for sediment source fingerprinting (Figure 5).

\section{Dating the Slackwater Sediments at Boila and the Onset of Late Upper Paleolithic Occupation}

The archaeological team collected charcoal fragments for radiocarbon dating from three horizons in the slackwater sequence. Figure 4(B) shows the stratigraphic relationship between the fine-grained slackwater sediments and the overlying deposits dominated by coarse angular limestone materials. It is clear in most of the excavation areas across the site that the upper part of the slackwater sediments has been disturbed by human activity, although the thickness of these upper alluvial sediments and the degree and vertical extent of disturbance vary across the site. The first secure evidence of in situ cultural material is associated with the upper part and surface of the fine-grained alluvial sediments (Kotjabopoulou et al., 1997; Figure 4[A]). These deposits are overlain across the site by sediments dominated by angular limestone clasts in a sandy-silt matrix (Figure 4[B]). The bulk of the sediments containing archaeological materials are comparable in many respects to the upper $2 \mathrm{~m}$ of the sedimentary fill at Klithi rockshelter that contains the Late Upper Paleolithic culture at that site (see Bailey and Woodward, 1997). The sequences at Boila and Klithi will be discussed further below. These scree sediments contain a much higher concentration of archaeological material (see Kotjabopoulou et al., 1997). Late Upper Paleolithic materials have also been recovered from the fine alluvial sediments overlying Sequence B (Figures 4[A] and 4[B]) (Kotjabopoulou et al., 1999), and charcoal samples from the uppermost alluvial sediments have yielded ages of 13,810 \pm 130 (OxA-5246) and 13,960 $\pm 260 \mathrm{yr}$ B.P. (Beta 109162) (Figure 5). The slackwater sediments were deposited before the Late Upper Paleolithic use of the site. The two radiocarbon ages associated with this cultural activity provide a minimum age for the end of flood inundation and slackwater deposition in the rockshelter.

Away from the bedrock wall, the thickness of the slackwater deposits (Sequence 
WOODWARD ET AL.

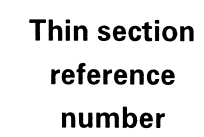

$33 a$

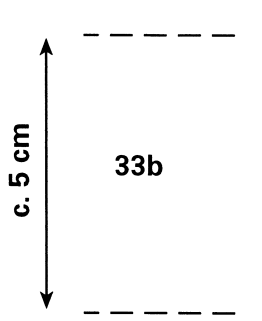

$33 c$

33d

$33 e$

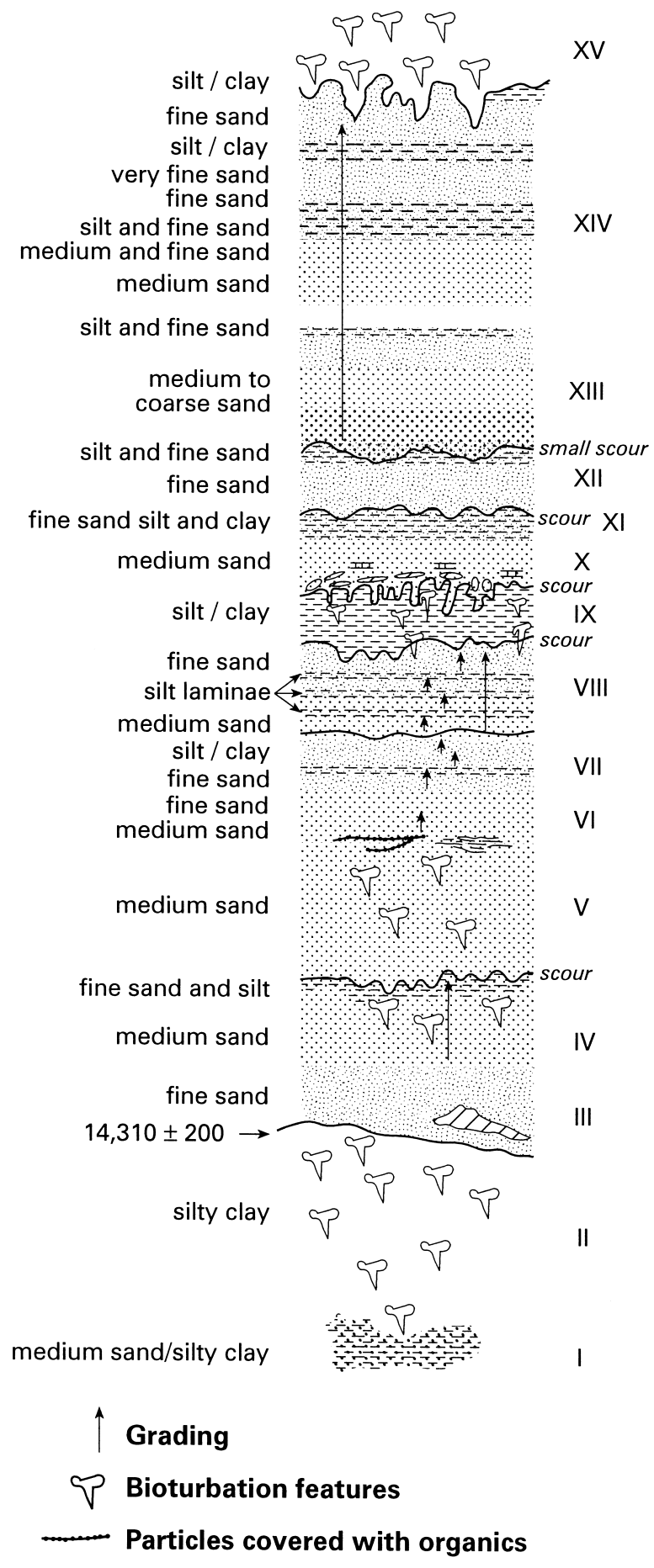


B) decreases significantly, and the deposits rest directly upon the terraced surface of the coarse-grained fluvial gravels via an erosional surface (Figure 4[A]). Micromorphological and field observations of this transition have shown that it contains an abundance of dispersed angular charcoal fragments (Table I and Figure 7[B]). Excavation in this area revealed a hearth resting upon the (undulating) terrace surface; the charcoal yielded a radiocarbon age of $14,310 \pm 200 \mathrm{yr}$ B.P. (Beta109187). This hearth is not associated with lithic or faunal materials, but it may represent a brief visit to the site during the main phase of occupation at Klithi rockshelter upstream (see Bailey and Woodward, 1997).

The major phase of slackwater sediment deposition within the rockshelter site took place after ca. 14,310 \pm 200 radiocarbon yr B.P. and ended around 13,960 \pm 260 yr B.P. (Figure 5). The brownish-colored, fine-grained slackwater sediments, shown as weathered alluvium on Figure 4(A), were deposited before this period and after the deposition of the coarse limestone-rich gravels below. Micromorphological observations show that alluvial Unit 1 is weathered and contains a significant component of flysch-derived clay and silt (Table I). Previous work on the alluvial sediments and landforms in the Voidomatis catchment identified a Late Pleistocene (Vikos) alluvial unit that yielded a thermoluminescence age of 19,600 \pm 3000 yr B.P. (see Lewin et al., 1991). This unit records an increase in flyschderived coarse and fine sediments after the Last Glacial Maximum, and the weathered fine sediments above the cold stage gravels of Sequence A may have been deposited during this period (see Macklin et al., 1997; Woodward et al., 1992).

\section{Incision of the Voidomatis River and Late Upper Paleolithic Occupation}

The rockshelter floor currently lies about $11 \mathrm{~m}$ above the modern river channel in one of the narrowest parts of the Lower Vikos Gorge. While the precise level of the river during the Lateglacial period is not known, extreme flood flows would have been accompanied by major increases in flood stage in this confined reach. Inundation of the site and slackwater sedimentation ceased after ca. 13,960 \pm 260 yr B.P.; fluvial sediments are not present in the overlying archaeological deposits that cover a period of approximately 3500 radiocarbon years (Kotjabopoulou et al., 1999). It can be argued that the rockshelter would not have been a favorable location for periods of intense occupation over such a long period if it had been susceptible to ponding and repeated inundation by floodwaters. It is likely that the large floods represented by the slackwater sediments were responsible for at least part of the major phase of valley floor incision that left the rockshelter floor ele-

Figure 6. Schematic diagram of the sedimentary features within the slackwater sequence derived from analysis of thin sections manufactured from resin-impregnated blocks of sediment. Note that each thin section is approximately $5 \mathrm{~cm}$ in length (top to bottom). This sequence represents alluvial units 2 and 3 as shown in Figure 5 and the top of Sequence A. Sampling is continuous; the thin sections overlap one another. Grain size data are based on visual estimates from thin sections. 

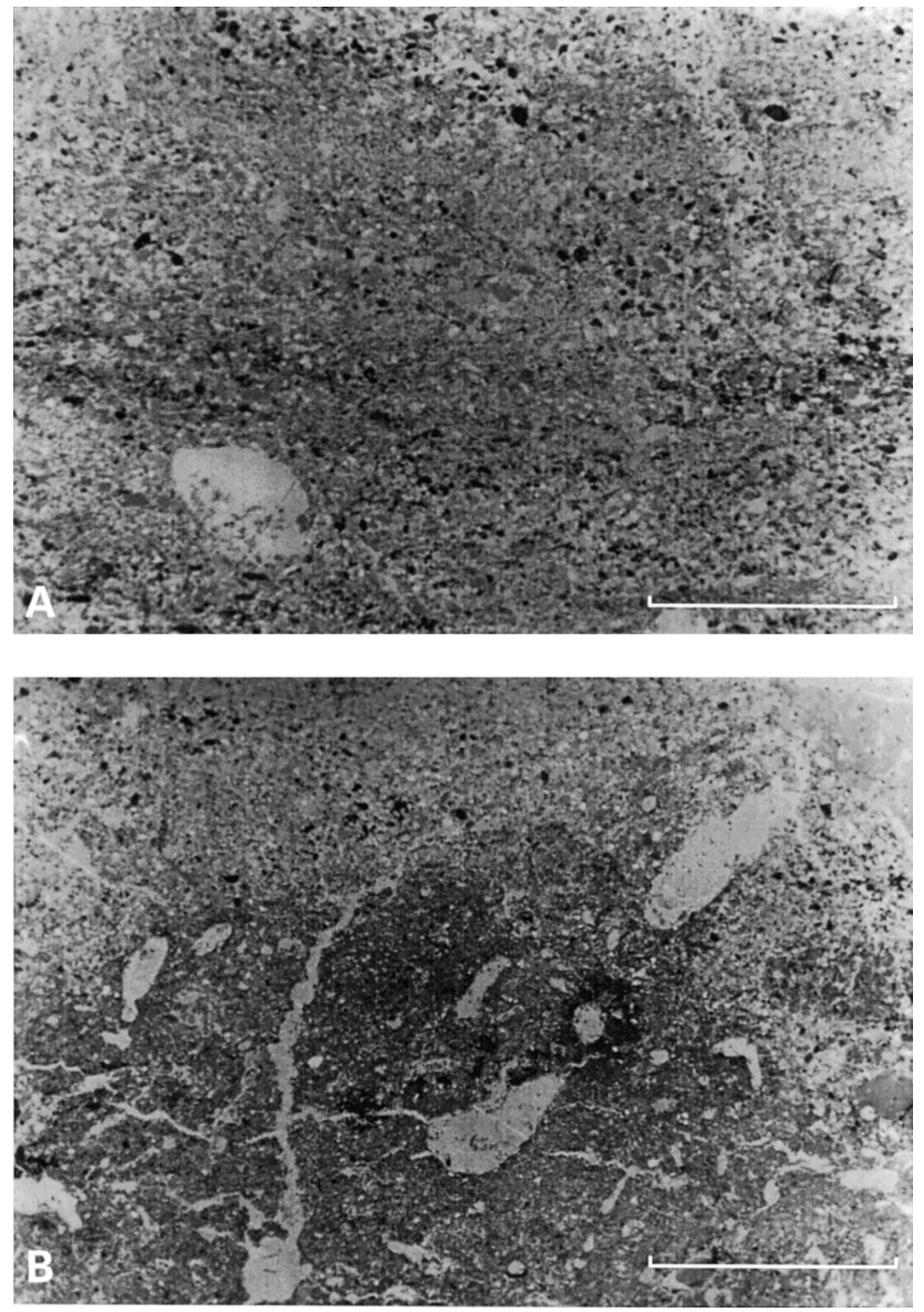

Figure 7. The micromorphology of the fine-grained slackwater sediments at Boila. (A) Coarse-fine laminae in the central part of the slackwater deposits (XII) and (B) the contact between the weathered alluvial sediments of sequence $A$ and the fine sands at the base of the slackwater sediments (sequence B) (II-III). See Figure 6 for thin section locations (Roman numerals). 
Table I. Description of the thin sections from the slackwater sequence at Boila. ${ }^{\text {a }}$

I-II: Unsorted massive, light brown, silty clay, strongly bioturbated with channel and chamber voids. The fine matrix is dominated by fine calcite particles mixed with clay. Charcoal fragments are adundant. In the lower part (I) relict sedimentary features such as stratified sands and laminations are preserved. The upper boundary is abrupt. I and II are alluvial sediments that have been subaerially weathered.

III: Fine sand with some horizontal orientation of the limestone particles and moderate sorting. Evidence of bioturbation is generally absent except in the upper part.

IV: Medium sand which grades upwards to fine sand. Evidence of weak bioturbation with some calcite coatings on channel and chamber voids. The limestone particles have a preferred horizontal orientation and moderate sorting. The upper boundary is very rough and represents a scour surface.

V: Medium sand, well sorted with preferred horizontal orientation of the limestone particles. Evidence of weak bioturbation with some channel and chamber voids coated with calcite. The upper boundary is characterized by silty laminae, and the particle surfaces are covered with an organic film, although its exact composition is not clear.

VI: Medium sand which grades upwards to fine sand. No evidence of bioturbation, but the upper sediments are well sorted.

VII: At least four couplets of medium sand and fine sand to silt and clay are present in this part of the sequence. The laminae are between $0.5 \mathrm{~mm}$ (upper part) and $2 \mathrm{~mm}$ (lower part) in thickness. The finer part of the lower couplet contains current ripples which form local microscopic cross stratification. There is preferred horizontal orientation of the limestone particles. The upper boundary is characterized by clasts with a surface coating or organic film. The upper boundary also contains current ripples.

VIII: Well-laminated sediments which grade upward from medium sand to fine sand interrupted by silt laminae. At least five couplets of medium to fine sand and silt (each laminae is 1-2 mm in thickness) can be identified. The sediments are well sorted, and there is preferred horizontal orientation of the limestone particles. A single gastropod shell was observed. The upper fine sand laminae are very well sorted, but the limestone particles do not show any preferred orientation. The upper boundary is a scour surface.

IX: Well-laminated clay-silt with silt-rich and clay-rich laminae. Preferred orientation of mica flakes and some clay strings. Very dense packing of the particles. Current ripples in the finer parts and formation of microscopic cross-stratification. Moderate bioturbation with some channel and chamber voids lined with calcite. Rounded clay aggregates derived from soils are abundant. The upper boundary is very rough and bioturbated, with a significant amount of fragmented redeposited material incorporated in the overlying sediments.

X: Medium sand with a few laminae 1-2 mm in thickness composed of flysch-derived materials or limestone particles. A few laminae of silt are also present. The limestone particles display a preferred horizontal orientation.

XI: Poorly sorted silt to fine sand with some clay delineating rippled surfaces (microscopic crossstratification). The upper boundary is a scour surface.

(Continued) 
WOODWARD ET AL.

Table I. (Continued)

XII: Fine sand which grades upwards to fine sand and silt. The upper part is poorly sorted and the upper boundary is a weak scour surface.

XIII: Coarse to medium sand with very weak preferred orientation of the particles and no evidence of grading. Some lenticular laminae of flysch-derived silt particles are also present. Thin laminae of finer material are present in the upper part.

XIV: This part of the sequence contains at least three coarse and fine couplets which grade upwards. The grading between the coarse-fine laminae of each couplet is rather abrupt. The coarse increments grade from coarse and medium sand to fine sand, and the fine increments from fine sand to silt and clay with current ripples and microscopic cross-stratification. The limestone particles are weakly oriented in the upper coarse sediments. The finer laminae are often disrupted and were eroded during the deposition of the overlying sediments. The upper boundary is rather abrupt and very rough.

XV: Light brown, massive, silty clay, strongly bioturbated. Some channel and chamber voids are filled with calcite. The fine matrix is dominated by fine calcite particles mixed with clay particles. These are alluvial sediments that have been subaerially weathered.

a The stratigraphic context of each thin section is shown in Figure 6.

vated above the highest flood stage for the rest of the Lateglacial period and available for repeated use by Paleolithic foragers for the first time. The Boila sequence could also reflect a general decrease in flood magnitude in the catchment after ca. 13,900 radiocarbon yr B.P., when flood flows were not high enough to inundate the site.

\section{DETERMINING THE SOURCE OF THE SLACKWATER SEDIMENTS USING A QUANTITATIVE FINGERPRINTING APPROACH}

\section{Background}

The nature and the age of the slackwater deposits at Boila are especially significant because alluvial sediments and landforms that date to the Lateglacial period have not been widely preserved in the Voidomatis River basin (see Lewin et al., 1991; Macklin et al., 1997). We have developed a methodology to obtain information on the source of these slackwater sediments because such data could provide valuable insights into the nature of the wider Voidomatis catchment during the period of slackwater deposition immediately prior to the Late Upper Paleolithic use of Boila. In addition, this important period overlaps with the major phase of Late Upper Paleolithic occupation at Klithi rockshelter (Bailey and Woodward, 1997), the largest site in the area, and the slackwater sediments at Boila present an opportunity to shed light on the nature of the Voidomatis catchment during at least part of the occupation at Klithi.

Earlier work on alluvial sediment sources in the Voidomatis catchment highlighted the contrast between the composition of the suspended sediment load dur- 
ing cold glacial phases of the Pleistocene and the modern interglacial system (Woodward et al., 1992). This work used semiquantitative peak height data from $\mathrm{X}$-ray diffraction traces to differentiate between sediments rich in calcium carbonate derived from the glaciated limestone headwaters from sediments derived from flysch rocks and soils and characterized by plagioclase, quartz, mica, and other clay minerals (see Figure 1).

Marked contrasts in relief and rock type allow the catchment to be divided into five terrain units, shown in Figure 1 (see Lewin et al., 1991; Bailey et al., 1997). The mountainous headwaters of the Voidomatis basin contain extensive Pleistocene moraines where deep sections expose an abundant fine-grained till matrix largely derived from glacially comminuted limestone bedrock. The flysch rocks comprise sandstones interbedded with erodible siltstones and these terrains are often deeply gullied with poorly developed soils (Woodward et al., 1992; Bailey et al., 1997). The flysch deposits are an important source of suspended sediment in the contemporary river system, and they dominate the silt and clay fraction of the suspended load.

\section{The Sediment Fingerprinting Approach}

The fingerprinting approach involves, first, the selection of a physical or chemical property which clearly differentiates potential catchment source materials and, second, comparison of measurements of the same property obtained from the target sediment (in this case, the slackwater sediments in the rockshelter) with the equivalent values for the potential sources (Walling and Woodward, 1992; Bottrill et al., 2000). Peart and Walling (1988) recommended the use of several fingerprint properties or tracers to increase the reliability of the results obtained and to permit a substantial number of potential sources to be discriminated by their fingerprints. Work on contemporary fluvial systems has shown that it is important to identify physical or chemical properties that vary over a substantial range and are therefore able to distinguish different sources in an unequivocal manner (Walling and Woodward, 1992). The use of several diagnostic properties (rather than a single indicator) is to be recommended and Walling et al. (1993) and Walling and Woodward (1995) used the terms multiparameter or composite sediment fingerprints, which exploit a range of tracer properties. This is the approach used in this investigation, and a linear mixing model has been used to estimate the contributions from the source groups identified (see Walling et al., 1993).

In view of the widely contrasting lithological source types (including limestone, flysch, and ophiolite rocks) present in the catchment (Figure 1), we have used trace element composition and two mineral magnetic parameters to characterize the source groups. Their selection is explained in the next section. Mineral magnetic parameters have previously been used to identify the source of fluvial suspended sediment and estuarine and lacustrine sediments (see Yu and Oldfield, 1989; Foster et al., 1990; Slattery et al., 2000). The quantitative fingerprinting approach has now been tested in a wide range of settings to estimate sediment source contributions 
for suspended sediments and fine-grained alluvial, estuarine and reservoir sediments in river catchments of various sizes (see Yu and Oldfield, 1989, 1993; Walling et al., 1993; Walling and Woodward, 1995; Collins et al., 1997, 1998; Bottrill et al., 2000; Hamlin et al., 2000).

\section{Identification of the Composite Sediment Fingerprint}

The aim of this approach is to employ a range of sediment (tracer) properties to generate an objective estimate of the relative contribution of the potential sediment sources listed in Table II to the slackwater sediments preserved in Boila rockshelter. In order to achieve this, we must address four main requirements:

1. A range of fingerprint properties must be identified that are capable of discriminating between the potential sediment sources listed in Table II.

2. The selected combination of sediment properties must satisfy appropriate statistical tests of significance to establish that each of the sediment sources is clearly distinguished by its composite fingerprint.

3. An objective algorithm, capable of comparing the composite fingerprint of a slackwater sediment sample with those of all potential sources and providing an estimate of the likely relative contributions of those sources to that sample, must be used.

4. The results of the quantitative fingerprinting approach must be tested using independent data.

\section{Field and Laboratory Methods for Sediment Source Fingerprinting}

As we have described above, the exposed sections at Boila were logged and photographed in the field, and samples of each of the sedimentary units were taken for sedimentological and geochemical analysis (Figure 5).

Potential source materials were sampled throughout the catchment and are listed in Table II. From field observations and analysis of geological maps and aerial photographs, eight potential sediment source groups have been identified in the Voidomatis catchment. Each of these sources was sampled with the number of

Table II. Potential sources of fluvial sediment identified in the Voidomatis catchment (after Hamlin et al., 2000) and the number of samples collected from each source group.

\begin{tabular}{lc}
\multicolumn{1}{c}{ Source Group } & Number of Samples \\
\hline 1. Limestone bedrock & 13 \\
2. Pleistocene till & 4 \\
3. Flysch bedrock & 18 \\
4. Dolomite-enriched flysch bedrock & 2 \\
5. Dolomite bedrock & 1 \\
6. Ophiolite bedrock & 3 \\
7. Pleistocene terra rossa (soil) & 4 \\
8. Reworked Late Pleistocene alluvium & 7 \\
\hline
\end{tabular}


samples broadly reflecting the extent of these sediments or rock types in the basin (Figure 1). Woodward et al. (1992) used X-ray diffraction data to make semiquantitative comparisons between the first three source groups listed in Table II and fine sediments preserved within Pleistocene and Holocene alluvial units and the modern river channel. The use of a quantitative composite fingerprint based on a range of tracer properties allows a larger number of potential sediment sources to be considered and may, therefore, provide a more detailed reconstruction of the catchment conditions associated with the large flood events that produced the slackwater sediments at Boila.

Examination of the source groups listed in Table II reveals a wide range of markedly contrasting lithologies including sedimentary and igneous rocks and strongly weathered Pleistocene soils. Trace element data were employed to provide the main basis for source group discrimination as chromium and nickel are abundant in ultramafic rocks, strontium is abundant in carbonate rocks, and barium and copper, for example, are common in shales and sandstones. The fingerprinting properties employed should be present in measurable concentrations in as many of the identified source groups as possible. They must also exhibit conservative behavior during transport and deposition. Geochemical (trace elements) and mineral magnetic parameters were selected to quantify the composition of the source materials as these satisfy both requirements. Chromium and zirconium, for example, have been used as resistant indices in many studies of tropical weathering because they are immobile in many contexts.

The use of contrasting tracer properties, which reflect different environmental controls, is likely to produce more reliable source group differentiation (see Walling and Woodward, 1995). Samples of the source materials (including powdered bedrock samples) were analyzed by X-ray fluorescence to determine the concentration of $\mathrm{Ba}, \mathrm{Cu}, \mathrm{Cr}, \mathrm{La}, \mathrm{Nd}, \mathrm{Ni}, \mathrm{Pb}, \mathrm{Rb}, \mathrm{Sr}, \mathrm{V}, \mathrm{Y}, \mathrm{Zn}$, and $\mathrm{Zr}$. Low frequency magnetic susceptibility and frequency dependent magnetic susceptibility were also determined on these samples using a standard Bartington MS2 duel frequency meter (see Thompson and Oldfield, 1986). Ten sediment samples from the alluvial sequence at Boila were analysed using the $<2 \mathrm{~mm}$ fraction for X-ray fluorescence and the $<1 \mathrm{~mm}$ fraction for magnetic susceptibility (Figure 5). Thus, in total, the laboratory analysis produced 15 parameters whose characteristics (individually and collectively) could be tested to obtain the best parameter combination or "composite fingerprint" for effective source group discrimination (see Walling and Woodward, 1995; Collins et al., 1997; Hamlin et al., 2000; Bottrill et al., 2000).

\section{Testing Source Group Discrimination Effectiveness for Each Parameter}

The sediment properties used to fingerprint the slackwater sediments should clearly differentiate among all potential sources in the Voidomatis catchment (Table II). To fully exploit the potential of composite fingerprints, it is important to test the extent to which they are capable of differentiating the potential source groups and thus to confirm that each source has a composite or multiparameter 
fingerprint which is significantly different from that of the other sources (Walling et al., 1993). It is also necessary to identify those properties that cannot distinguish between the source groups and to remove them from subsequent analysis (see Bottrill et al., 2000).

The first data processing stage identifies the most appropriate combination of sediment properties to produce the composite fingerprints for each of the source groups (see Collins et al., 1997; Hamlin et al., 2000). First, to ensure that each parameter exerts an equal influence in the fingerprinting model, all the analytical data were made dimensionless by dividing the values for each parameter by the maximum measured value (see Verruchi and Minisale, 1995). Nonparametric Kruskal-Wallis $H$-tests were then used to identify the combination of trace elements and mineral magnetic parameters that could characterize the eight sediment source groups (Table III). The results of this test show that, apart from frequency-dependent magnetic susceptibility, all of the parameters show $H_{\text {calc }}$ values greater than $H_{\text {crit }}$ at the $99.9 \%$ significance level. Thus, there is a $99.9 \%$ probability that the contrasts between the source groupings based on these parameters are not due to random variation. Frequency-dependent susceptibility is a measure of the concentration of very fine-grained superparamagnetic particles, but they are not present in sufficient concentrations in all of the source types to permit effective discrimination (Hamlin et al., 2000). This parameter is, therefore, rejected at this stage with no further part to play in the fingerprinting procedure. All the trace elements and magnetic susceptibility (which is a measure of the total concentration of magnetic minerals in a sample) pass this source group discrimination test (Table III).

Table III. Kruskal-Wallis $H$-test results for the parameters used to characterize the source groupings. ${ }^{a}$

\begin{tabular}{lc}
\hline \multicolumn{1}{c}{ Tracer Property } & $H$-Value \\
\hline Barium (Ba) & 45.18 \\
Chromium (Cr) & 46.65 \\
Copper (Cu) & 38.22 \\
Lanthanum (La) & 39.29 \\
Neodymium (Nd) & 38.82 \\
Nickel (Ni) & 46.67 \\
Lead (Pb) & 45.46 \\
Rubidium (Rb) & 44.98 \\
Strontium (Sr) & 44.96 \\
Vanadium (V) & 43.61 \\
Yttrium (Y) & 47.55 \\
Zinc (Zn) & 45.11 \\
Zirconium (Zr) & 47.78 \\
Magnetic susceptibility ( $\chi$ ) & 43.02 \\
Frequency-dependent mag sus $(\% \chi \mathrm{fd})$ & 14.30 \\
\hline
\end{tabular}

a The critical values are also given. Note that $H$-values greater than the critical value indicate that the tracer property provides a statistically significant characterization of source groupings. $H_{\text {crit }}=14.07$ (95\%), 24.32 (99.9\%). 


\section{Testing the Reproducibility of the Analytical Measurements and the Long-term Stability of the Fingerprinting Parameters}

To test for analytical reproducibility, repeat analyses of the same sample aliquot for a randomly selected $10 \%$ of the sample set were carried out. The replicates were divided by their mean and a weighting ( 1 - the standard deviation) was calculated for each parameter (Table IV). Apart from lanthanum (La) and neodymium (Nd), all the parameters demonstrate very good reproducibility with weightings ranging from 0.976 to 0.822 . Both $\mathrm{La}$ and $\mathrm{Nd}$ are light rare earth elements and may be unstable under certain diagenetic conditions. In view of their poor reproducibility and potential long-term instability (i.e., non-conservative behavior following erosion from source and deposition), these two parameters were removed from further analysis (see Hamlin et al., 2000).

\section{Selection of the Parameters for the Composite Fingerprint Using Multivariate Discriminant Analysis}

Multivariate Discriminant Analysis (MDA) was used to select from the 12 remaining parameters a parameter combination that provides the most effective discrimination of the eight source groupings listed in Table II. Stepwise selection is achieved minimizing Wilk's lambda; the parameter with the lowest lambda value is selected at each step. The most useful tracer parameters (and therefore composite signatures) are associated with low lambda values because these indicate low within-group variance in relation to total variability. The results of this stage are listed in Table V. Because of the discriminatory power of these parameters, all the source samples are correctly classified by only four parameters, namely $\mathrm{Cr}, \chi, \mathrm{Zr}$, and Ba. Walling et al. (1993) have argued that a larger number of tracers with contrasting behavior will improve the reliability of the results, especially when

Table IV. Weightings for the fingerprint properties based on their analytical reproducibility.

\begin{tabular}{cc}
\hline Tracer Property & Weighting \\
\hline $\mathrm{Sr}$ & 0.976 \\
$\chi$ & 0.972 \\
$\mathrm{Zn}$ & 0.958 \\
$\mathrm{Ni}$ & 0.956 \\
$\mathrm{Zr}$ & 0.950 \\
$\mathrm{Y}$ & 0.947 \\
$\mathrm{Cr}$ & 0.934 \\
$\mathrm{Rb}$ & 0.930 \\
$\mathrm{Cu}$ & 0.927 \\
$\mathrm{Ba}$ & 0.860 \\
$\mathrm{~V}$ & 0.829 \\
$\mathrm{~Pb}$ & 0.822 \\
$\mathrm{La}$ & 0.572 \\
$\mathrm{Nd}$ & 0.219 \\
\hline
\end{tabular}


several potential sources are involved. With the addition of $\mathrm{Sr}, \mathrm{Y}, \mathrm{Rb}, \mathrm{Cu}$, and $\mathrm{V}$ there is a continued decrease in Wilk's lambda, indicating the improved discrimination (low within-group variance and higher intra-group variance) produced in this case by a larger composite fingerprint. Thus, the nine parameters listed in Table $\mathrm{V}$ formed the composite fingerprint for each of the eight catchment sources identified and provide the basis for establishing the source of the slackwater sediments at Boila.

\section{Estimating the Contribution of the Source Groups to the Slackwater Sediments at Boila}

The final stage in the sediment fingerprinting procedure involves the use of a linear mixing model to estimate the relative contribution from each of the sources to the slackwater sediment samples from the Boila sequence. Yu and Oldfield (1989) have described an optimized linear programming procedure for this purpose in their investigation of estuarine sediment sources in Chesapeake Bay, eastern United States. Walling et al. (1993) have employed a simpler approach that avoids the need to establish empirical equations based on artificial source group mixtures, and we have used this latter approach with the weighting procedure described by Collins et al. (1997) and Hamlin et al. (2000) (Table IV). In the linear mixing model used here, we assumed that the analytical data for the slackwater sediment samples are attributable to the relative contributions of the different catchment source groups:

$$
B_{t}=\sum_{s=1}^{S} V_{s t} P_{s}
$$

subject to the following set of linear constraints,

Table V. Selection of the tracers for the composite fingerprint based on multivariate discriminant analysis. $^{\mathrm{a}}$

\begin{tabular}{clc}
\hline Tracer Property & Wilk's Lambda & $\begin{array}{c}\text { \% of Samples } \\
\text { Correctly Classified }\end{array}$ \\
\hline $\mathrm{Cr}$ & 0.00789 & 75.00 \\
$\chi$ & 0.0000809 & 75.00 \\
$\mathrm{Zr}$ & 0.00000449 & 98.08 \\
$\mathrm{Ba}$ & 0.000000418 & 100.00 \\
$\mathrm{Sr}$ & 0.000000106 & 100.00 \\
$\mathrm{Y}$ & 0.0000000679 & 100.00 \\
$\mathrm{Rb}$ & 0.0000000312 & 100.00 \\
$\mathrm{Cu}$ & 0.0000000141 & 100.00 \\
$\mathrm{~V}$ & 0.00000000963 & 100.00 \\
\hline
\end{tabular}

${ }^{a}$ Note that all the source types listed in Table II have been correctly classified with only the first four parameters. 


$$
\begin{aligned}
& \sum_{s=1}^{S} P_{s}=1 \\
& 0 \leq P_{s} \leq 1
\end{aligned}
$$

while minimizing the error term,

$$
E=\sum_{t=1}^{T}\left\{\left[B_{t}-\left(\sum_{s=1}^{S} V_{s t} P_{s}\right)\right] / B_{t}\right\} W_{t}
$$

where $P_{s}$ is the percentage of material derived from source group $s, V_{s t}$ is the mean value of tracer property $t$ for source group $s, S$ is the number of source groups, $B_{t}$ is the slackwater sediment sample value for tracer property $t, W_{t}$ is the weighting for tracer property $t$ (see Table IV, Hamlin et al., 2000), and $T$ is the number of tracer properties considered in the fingerprinting model (see Walling et al., 1993; Walling and Woodward, 1995). To take account of the analytical reproducibility test shown in Table IV, the tracer properties have been weighted according to these results. The mixing model used here sets the initial values for $P_{s}$ (the percentage of material from each source group) to be equal (in this case 12.5\%), and the error term $E$ is calculated as a measure of the goodness of fit between the measured and predicted tracer values for each slackwater sediment sample. New errors are calculated for a series of changes in the values of $P_{s}$, and this proceeds until no further reduction in the error term is possible and the optimum estimate for relative source contributions is obtained (see Walling and Woodward, 1995). The values of $P_{s}$ associated with the minimised error term give the sediment source contribution estimates as percentages. The $<2 \mathrm{~mm}$ fraction of all samples was analyzed for trace element concentrations, but because many of our source material samples are powdered bedrock (Table II), we have not incorporated a particle size correction factor in the mixing model optimizing algorithm (see Bottrill et al., 2000). This is discussed further below.

\section{RESULTS AND DISCUSSION}

The results of the quantitative fingerprinting analysis for the samples from the Boila slackwater sequence are shown in Figure 8. It is clear that the slackwater sediments are largely derived from flysch rocks and soils with this component exceeding $80 \%$ for alluvial units 1, 2, 3 and the upper part of Unit 4. Limestone accounts for almost $60 \%$ of the fine sediments in the basal gravels, which is in good agreement with the lithology of the coarse fraction. Ophiolite is present in each of the samples, even though this lithology is present in restricted outcrops in the eastern headwaters of the Voidomatis river basin (Figure 1). The fingerprinting procedure indicates that sediments derived from terra rossa and dolomite are also present, but together they account for less than $10 \%$ of the total.

Whenever possible, it is desirable to evaluate the fingerprinting results using 


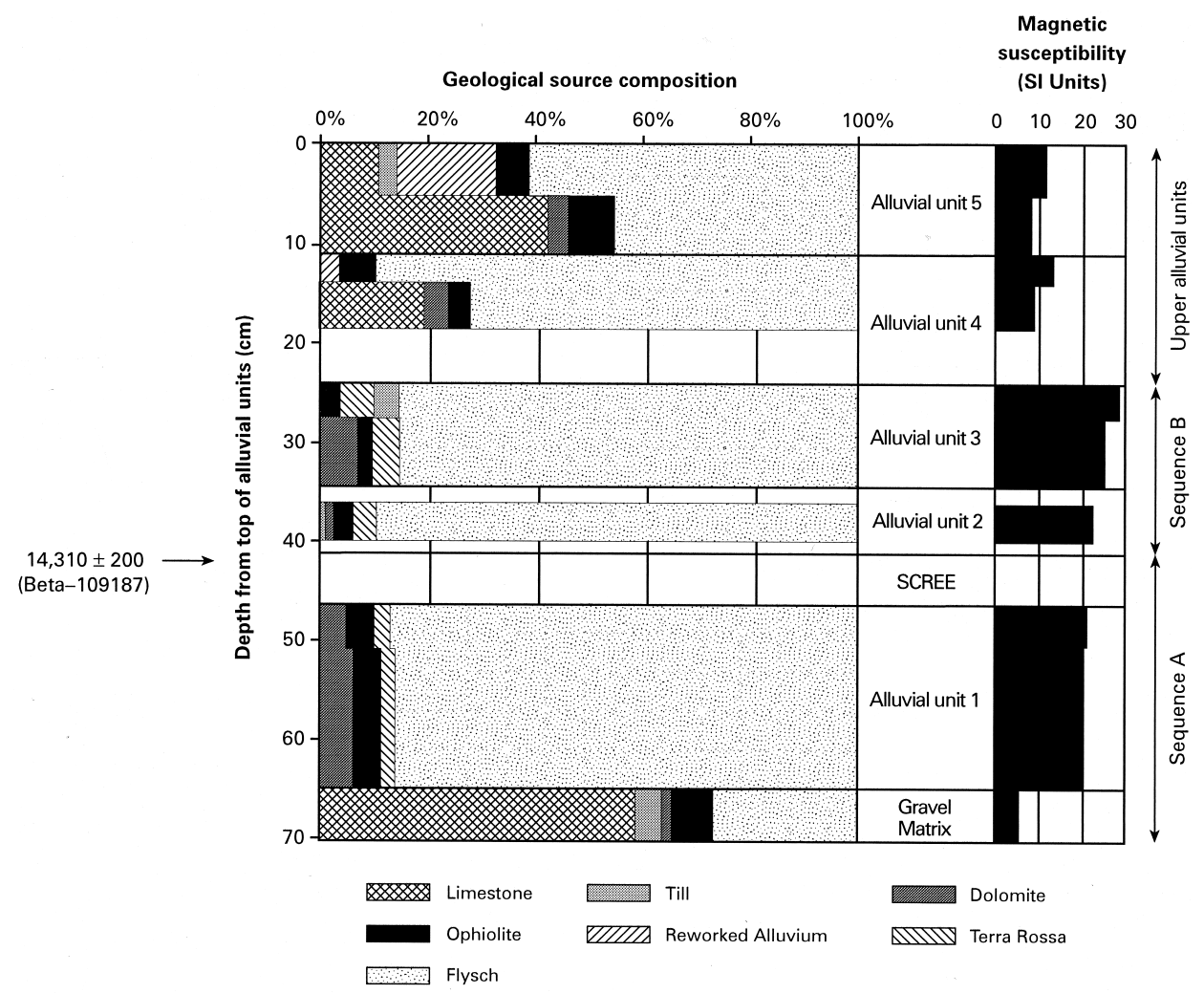

Figure 8. Results of the quantitative sediment fingerprinting procedure for the slackwater sediments at Boila (alluvial units 1-5) and the fine-grained matrix in the coarse gravels below. Note that the results shown here are for the samples marked with an asterisk in Figure 5.

independent data (see Rowan et al., 2000). For the Boila slackwater sediments, we have used micromorphology and X-ray diffraction techniques. Some examples of these approaches are discussed below. Detailed quantitative estimates of lithological composition have not yet been carried out on the thin sections. However, the mineral suites identified in the slackwater sequence from micromorphological analyses offer one means of testing the reliability of the sediment fingerprinting results. These data provide a very valuable check on the accuracy of the source component estimates produced by the composite sediment fingerprinting approach.

Interestingly, the micromorphological analyses have demonstrated that all of the samples contain a small ophiolite component, which provides support for the sediment fingerprinting results. Ophiolite is present in limited outcrops in the southeast of the catchment (Figure 1), and the bed sediments of streams draining this terrain contain an abundance of ophiolite material (Lewin et al., unpublished data). Lewin et al. (1991) identified an ancient alluvial unit ( $>20 \mathrm{~m}$ in thickness) in the upper 
reaches of the Voidomatis basin with a clast lithological composition of $44 \%$ ophiolite. These materials, reworked during large flood events, could have been an important source of fine-grained ophiolite material. Several ophiolite-derived minerals have been identified in thin section at Boila, including actinolite, spinels, titanite, serpentine, and magnetite. The ophiolite in the basin has been described as a spinel harzburgite (Woodward, 1990) with a very distinctive trace element composition that is quite different from any of the other source groups (Table VI). It is characterized by relatively high concentrations on $\mathrm{Cr}$ and low values of $\mathrm{Sr}$ and $\mathrm{Ba}$. Its presence in each of the samples provides evidence for the importance of floodwater generating runoff events in the eastern and southern part of the catchment and suggests that the flysch basins in this headwater area were the dominant source of fine sediment during these flood events (Figure 1).

The fingerprinting results indicate that alluvial units 1,2 , and 3 contain a minor amount of terra rossa (Figure 8), but it is difficult to be certain if this represents a real contribution or an artifact of in situ alteration. Terra rossa aggregates were not observed in the thin sections, and if reworked terra rossa materials are present in the slackwater sediments, they are likely to be in the form of very fine clay particles. Further micromorphological or selective X-ray diffraction analysis could resolve this issue. Alluvial units 4 and 5 at the top of the slackwater sequence contain a significant amount of limestone and small amounts of dolomite as well as some reworked alluvium (Figure 8). These sediments contain Late Upper Paleolithic archaeological materials - albeit in low concentrations - and have been disturbed by human activity. Micromorphological investigation of these sediments has shown that sand-sized angular fragments derived from the rockshelter bedrock wall are the main source of the limestone component. The morphology of the sand-sized limestone particles observed in thin section proves their proximal (autogenic) source, and their origin is quite different from the limestone component in the basal gravel matrix that represents a distal allogenic main channel source. In common with the earlier fine-grained units, the alluvial component of these sediments is also mainly derived from erodible flysch terrains. The composition of the upper flood sediments is in good agreement with the evidence for human disturbance and sediment mixing revealed from excavation and micromorphological analysis.

Micromorphological observations of alluvial units 2 and 3 (Sequence B, Figure 6) show that the coarser flysch material consists of subrounded to well-rounded particles of silty quartz, feldspar, and some mica flakes embedded in an illite or other clay matrix (Figure 7). This mineral assemblage has been confirmed by X-ray diffraction analysis of the fine-grained sediments at Boila (see Hamlin et al., 2000). These particles usually have a weathered and oxidized appearance, indicating that they have been derived from exposed and weathered parts of the flysch rocks and soils. The finer flysch material is mainly in the form of single mineral grains of quartz, feldspar (plagioclase, microcline, orthoclase), mica flakes, illite or other clays, and chlorite. These mineral grains are more or less subangular. The lithological data derived from the thin sections show that limestone forms an important part of the sand fraction in this part of the sequence, but this lithology is not 
Table VI. Mean values of fingerprint properties used in the composite fingerprint for the eight source groupings. ${ }^{\mathrm{a}}$

\begin{tabular}{|c|c|c|c|c|c|c|c|c|c|}
\hline & & Limestone & Till & Flysch & $\begin{array}{l}\text { Dolomite-Enriched } \\
\text { Flysch }\end{array}$ & Dolomite & Ophiolite & Terra rossa & $\begin{array}{c}\text { Reworked } \\
\text { Alluvium } \\
\end{array}$ \\
\hline \multirow[t]{2}{*}{$\mathrm{Ba}$} & Mean & $38(7)$ & $118(6)$ & $302(4)$ & $1034(1)$ & $964(2)$ & $25(8)$ & 429 (3) & $132(5)$ \\
\hline & $\% \mathrm{CV}$ & 59.3 & 22.1 & 20.7 & 32.9 & & 18.4 & 6.2 & 71.8 \\
\hline \multirow[t]{2}{*}{$\mathrm{Cr}$} & Mean & $7(8)$ & $48(5)$ & $265(3)$ & $97(4)$ & $13(7)$ & 2831 (1) & $454(2)$ & 47 (6) \\
\hline & $\% \mathrm{CV}$ & 38.6 & 29.3 & 18.8 & 66.7 & & 4.5 & 37.8 & 26.7 \\
\hline \multirow[t]{2}{*}{$\mathrm{Cu}$} & Mean & $9(8)$ & $24(4)$ & $35(3)$ & $56(2)$ & $16(7)$ & $19(6)$ & $89(1)$ & $24(4)$ \\
\hline & $\% \mathrm{CV}$ & 34.9 & 6.6 & 48.2 & 57.0 & & 3.5 & 27.1 & 18.8 \\
\hline \multirow[t]{2}{*}{$\mathrm{Rb}$} & Mean & $3(7)$ & $26(4)$ & $88(2)$ & $68(3)$ & $11(6)$ & $1(8)$ & $103(1)$ & $19(5)$ \\
\hline & $\% \mathrm{CV}$ & 28.7 & 20.4 & 48.6 & 52.7 & & 41.6 & 7.1 & 19.2 \\
\hline \multirow[t]{2}{*}{$\mathrm{Sr}$} & Mean & $538(2)$ & $482(4)$ & $178(6)$ & $971(1)$ & $203(5)$ & bdl (8) & $121(7)$ & $514(3)$ \\
\hline & $\% \mathrm{CV}$ & 38.3 & 10.6 & 31.2 & 35.3 & & 0.0 & 57.2 & 4.9 \\
\hline \multirow[t]{2}{*}{$\mathrm{V}$} & Mean & $14(7)$ & $36(5)$ & $120(2)$ & $69(4)$ & $14(7)$ & $72(3)$ & $141(1)$ & $33(6)$ \\
\hline & $\% \mathrm{CV}$ & 37.2 & 27.1 & 38.2 & 57.0 & & 12.3 & 14.4 & 18.9 \\
\hline \multirow[t]{2}{*}{$\mathrm{Y}$} & Mean & $4(7)$ & $11(4)$ & $23(2)$ & $15(3)$ & $11(4)$ & bdl (8) & $63(1)$ & $9(6)$ \\
\hline & $\% \mathrm{CV}$ & 65.3 & 6.1 & 22.0 & 35.9 & & 0.0 & 17.0 & 11.6 \\
\hline \multirow[t]{2}{*}{$\mathrm{Zr}$} & Mean & bdl (8) & $32(4)$ & $148(2)$ & $39(3)$ & $12(6)$ & $2(7)$ & 204 (1) & $13(5)$ \\
\hline & $\% \mathrm{CV}$ & 0.0 & 30.2 & 16.2 & 97.0 & & 39.9 & 16.2 & 43.7 \\
\hline \multirow[t]{2}{*}{$\chi$} & Mean & $1.5(7)$ & $3.6(6)$ & $12.8(4)$ & $19.1(3)$ & $1.4(8)$ & $50.1(2)$ & $261.3(1)$ & $5.6(5)$ \\
\hline & $\% \mathrm{CV}$ & 133.9 & 4.3 & 28.6 & 52.6 & & 33.5 & 10.4 & 72.3 \\
\hline
\end{tabular}

${ }^{a}$ The coefficient of variance (\%) is also given. Trace element data are given in ppm (bdl = below detection limit). Units for magnetic susceptibility are $10^{-8} \mathrm{~m}^{3} \mathrm{~kg}^{-1}$. To emphasize the contrasting concentrations of each tracer property across the range of source types, the source group mean values for each tracer have been ranked. These rankings are given in parentheses. 
represented in the fingerprinting results. This may reflect the particularly finegrained nature of the flysch materials in this part of the sequence that have produced an enrichment effect in the trace element data (see Woodward and Walling, 1992; Bottrill et al., 2000). Particle size analysis of these sediments has shown that they are rich in silt- and clay-sized material and the component $>63 \mu \mathrm{m}$ is mainly fine sand (Hamlin, 2000). It is also important to consider the lithological complexity of this part of the sequence (as shown in Figure 6 and Table I), because only three samples have been taken in Sequence B for fingerprinting, and these may be dominated by, for example, the fine-grained flysch-rich laminae. A marked limestone signal is present in the basal gravel matrix and in alluvial units 4 and 5 (Figure 8), which highlights the importance of testing the fingerprinting results with independent lithological data.

The results of the fingerprinting analysis for the sample taken from the matrix within the basal alluvial gravels is in good agreement with the micromorphological observations. It has a rather different composition than the overlying slackwater sediments because the source components are dominated by limestone. The gravels date to the last cold stage and the sandy fines could be derived from glacial crushing of limestone bedrock, from frost action on the gorge walls upstream, or from reworking of alluvial or colluvial sediments as well as from coarse particle attrition during transport (see Woodward et al., 1992). Micromorphological observations show that the matrix comprises unsorted, mixed limestone and flysch-derived material. The finer part of the matrix is dominated by a mixture of clay and very fine silt-sized calcite. This feature clearly differentiates the lower part of Sequence A from the overlying slackwater sediments, because fine silt-sized calcite has not been observed in the slackwater sequence where the sediments tend to be much better sorted. The coarse fraction is composed mostly of limestone clasts, and the rest is flysch-derived material. Woodward (1997a) has reported the presence of calcite rich silts in the lower part of Core Y25 at Klithi that penetrates deep into the pre-occupation ( $>17,000$ radiocarbon yr B.P.) sediments at that site. Woodward (1997a) has suggested that this fine silt material was blown into the rockshelter from the braided floodplain of the cold stage river, a conclusion supported by the presence of this distinctive material with the matrix of the cold stage gravels at Boila.

\section{Assessing the Extent of Postdepositional Alterations}

If the target sediments have been significantly modified by postdepositional processes, it is important to assess the extent of any diagenetic alteration, because this can exert an important influence on the fingerprinting results. Micromorphological analysis can be used to assess the nature and extent of sediment diagenesis (see Karkanas et al., 1999; Karkanas, 1997) and could be used to identify the most suitable sequences or horizons for quantitative sediment fingerprinting. Assemblages of micromorphological features can indicate the extent of $i$ situ weathering and may quantify the significance of any weathering products imported into the 
site by eolian, fluvial, or colluvial processes, for example. In some contexts, however, mineral magnetic analyses may provide a more objective and quantifiable assessment of diagenesis. The magnetic susceptibility data presented for each of the alluvial units in Figure 8 provides one potential measure of post-depositional weathering. All of the magnetic susceptibility values are $<30 \mathrm{~m}^{3} \mathrm{~kg}^{-1}$, and some of them are $<10 \mathrm{~m}^{3} \mathrm{~kg}^{-1}$. This contrasts markedly with values of $>150 \mathrm{~m}^{3} \mathrm{~kg}^{-1}$ observed for deeply weathered soils developed on terraced alluvial surfaces in the subaerial environment in the Lower Vikos Gorge (Woodward et al., 1994). Thus, while parts of the sequence show evidence of postdepositional alteration, this is limited in comparison to the weathering environment outside the rockshelter. Sequence $\mathrm{B}$, for example, is relatively unmodified (Figures 6 and 8).

More generally, information from micromorphological observations could be useful in the selection of sediment and source material sample pretreatments such as decalcification or particle size fractionation (see Walling and Woodward, 1992). The tracer properties employed to produce the composite fingerprints for a given study will need to be selected in accord with the nature of the regional geology and soil types (see Bottrill et al., 2000) and the nature of the rockshelter depositional environment under consideration (see Woodward and Bailey, 2000; Woodward and Goldberg, 2001). Interpretative models that assume a single source for the fine sediment fraction in a rockshelter or cave sediment sequence can be rigorously tested using this approach. The postdepositional modification of the rockshelter sediment record (including human impact) is an important factor that can affect the utility of this approach in a given setting. However, the extent of such modifications can be examined using micromorphological techniques and mineral magnetic measurements, and the utility of this approach must be assessed on a site by site basis. Rockshelters in passive karst settings (see Woodward and Goldberg, 2001), with limited postdepositional alteration of the sedimentary record, may form the most appropriate contexts for the successful application of this approach.

\section{LATEGLACIAL RIVER BEHAVIOR, ROCKSHELTER SEDIMENT SOURCES, AND THE LATE UPPER PALEOLITHIC RECORD AT BOILA AND KLITHI}

In chronological, cultural, and sedimentological terms, Boila forms a valuable local source of comparison with the record at Klithi. It also provides an opportunity to examine changes in foraging exploitation, settlement patterns, and environment at the end of the last cold stage. The Late Upper Paleolithic lithic and faunal record at Boila is discussed in its wider context by Kotjabopoulou et al. (1999) in relation to other sites in Epirus including Klithi and will not be repeated here.

Figure 9 shows the Late Pleistocene radiocarbon dates from Boila and Klithi plotted at 500-year intervals. It is clear that the Paleolithic use of Boila took place rather later than at Klithi, although there is some overlap between the two records. Kotjabopoulou et al. (1999) have argued that Boila was only used in the Lateglacial after the Voidomatis River had incised through the Late Pleistocene alluvial sedi- 


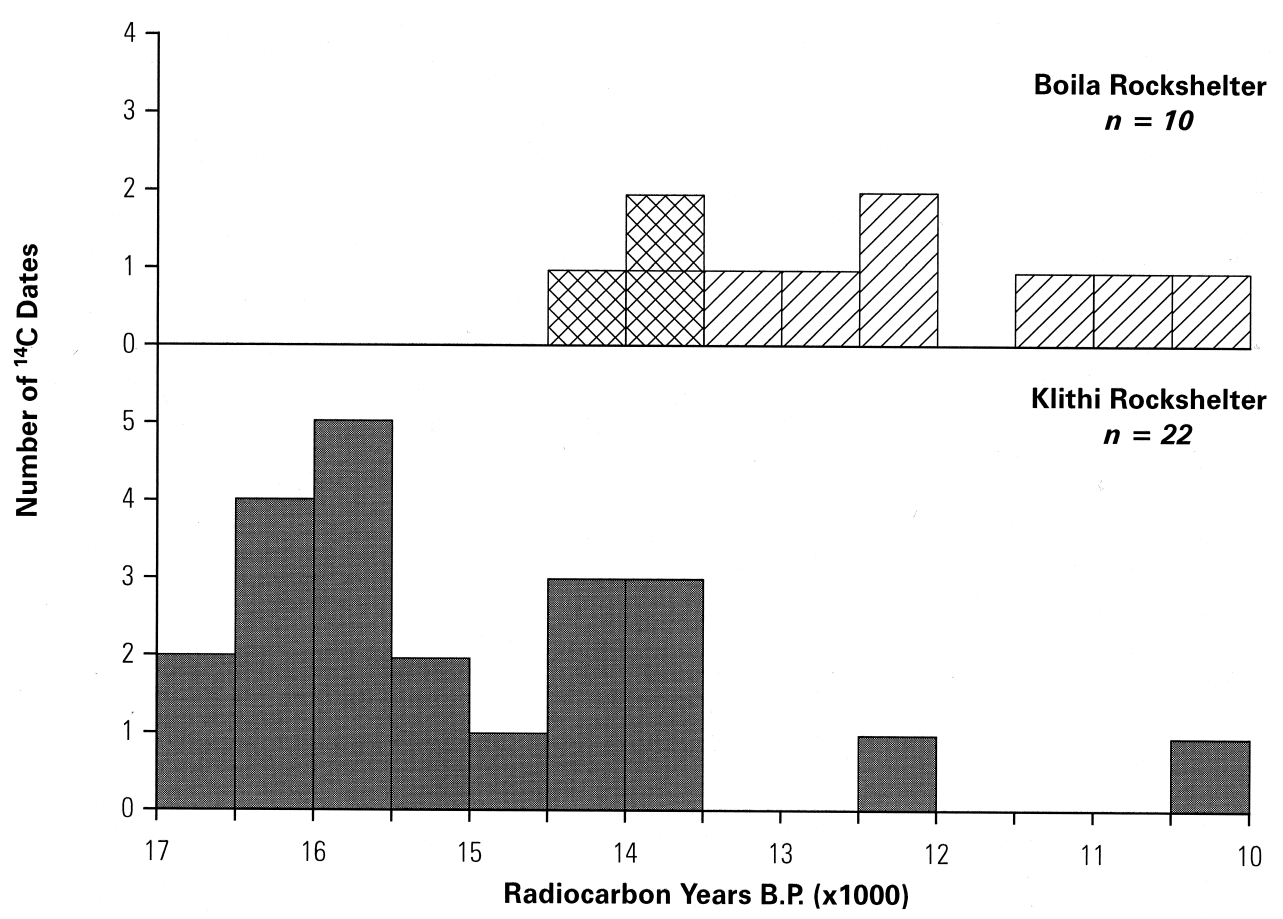

Figure 9. Radiocarbon dates from Klithi and Boila (after Bailey and Woodward [1997] and Kotjabopoulou et al. [1999] with additions). The three oldest radiocarbon dates from Boila (cross-hatching) are associated with the slackwater deposits (Figure 5). Note that the smaller sample of dates from Boila represent all those selected from key horizons submitted for analysis, and thus the frequency does not necessarily reflect intensity of occupation over time at this site. It is clear that the bulk of the occupation at Boila postdates the Late Upper Paleolithic occupation at Klithi. The Boila dating program is still in progress.

ments in that part of the gorge to leave the site above the highest flood stage. Klithi is $30 \mathrm{~m}$ above the present river in a much wider section of the Lower Vikos Gorge (Figure 2) and was available for use throughout the last cold stage. Paleolithic ibex and chamois hunters (Gamble, 1997) moved into the Voidomatis gorge after the recession of the Late Pleistocene ice sheets (Bailey et al., 1990; Woodward et al., 1995; Macklin et al., 1997). The cultural record from Boila indicates that huntergatherer groups made use of the resources provided by the Voidomatis basin and adjacent areas until at least the Pleistocene-Holocene transition.

One of the primary objectives of the Klithi project (1979-1989) was to establish the relationship of the Paleolithic sequence recovered from excavation to the environmental changes associated with the waxing and waning of the last glacial period (Bailey et al., 1984). This theme has been continued by the Boila project (Kotjabopoulou et al., 1997, 1999). The lithological composition and the age of the slackwater sediments beneath the Late Upper Paleolithic levels at Boila are signifi- 
cant in this respect because this information provides some useful insights into the nature of the Voidomatis catchment when Klithi was still a focus of intensive use. The archaeological materials at Klithi are concentrated in the upper $2 \mathrm{~m}$ of the rockshelter fill and are underlain by at least $5 \mathrm{~m}$ of sterile sediments. Sedimentological investigations of the $7 \mathrm{~m}$ Y25 core sequence at Klithi indicate that the site had not been inundated by floods during the Late Upper Paleolithic (Woodward, 1997a).

Radiocarbon dating indicates that the main period of occupation at Klithi is well bracketed between about 16,500 and 13,500 yr B.P., perhaps extending at the latest to about 12,400 yr B.P. with one date in the Younger Dryas (Bailey and Woodward, 1997; Figure 9). It seems clear that the main period of occupation, and certainly the great bulk of the artefactual and faunal evidence recovered in excavation, belongs to a relatively short interval of about 3500-4000 yr within the Lateglacial, sandwiched between conditions of extreme cold associated with the Last Glacial Maximum on the one side, and the rapid warming of the Bolling/Allerod interstadials on the other (Bailey, 1997b). The slackwater sediments overlap with the main phase of occupation at Klithi, which ended around 13,500 radiocarbon yr B.P. (Figure 9; Bailey and Woodward, 1997).

The dominance of flysch sources during the deposition of the slackwater sediments at Boila indicates that glacial activity was not a major supplier of sediment to the main Voidomatis channel at this time. In fact, a contribution from till is detectable in only three samples and, in each case, is minimal. This material may have been reworked by colluvial and fluvial processes after glacial activity had ceased. This signal is in marked contrast to fingerprinting data obtained from slackwater sediments at two other sites in the Lower Vikos Gorge that were deposited around the time of the Last Glacial Maximum (Hamlin, 2000). These sediments are dominated by sediments derived from limestone and till. The glacial deposits in the Tsepelovon district (Figure 1) are rich in limestone-derived sediments, and their absence suggests that the Boila flood events were generated primarily by heavy rainfall and/or snowmelt on lower-lying flysch basins. Reworked Pleistocene alluvium also forms a minor component of the slackwater sediments, which is to be expected in view of the major phases of valley-floor aggradation that took place in the basin during the Late Pleistocene (Lewin et al., 1991; Hamlin et al., 2000).

Bond et al. (1992) report uncalibrated radiocarbon dates which bracket Heinrich event 1 between ca. 13,490 \pm 220 and 14,590 \pm 230 yr B.P., which corresponds well with the dates obtained for the central and upper slackwater sediments at Boila (Figure 5). This period of intense cooling may have shifted the jet stream south, creating atmospheric instability and increased storm frequency in the Mediterranean region (see Prentice et al., 1992), resulting in valley-floor sedimentation (Fuller et al., 1998). However, Heinrich event 1 is not well represented in pollen records in the region, a time interval at Lake Ioannina represented by a gradual increase in deciduous oak pollen and other tree species, although some steppic elements are also present (see Galanidou et al., 2000). The three radiocarbon ages from the slackwater deposits at Boila have been calibrated using the OxCal pro- 
gram (Table VII). These data suggest that the central and upper part of the sequence was deposited within a relatively short interval, which agrees well with the micromorphological data showing that the Sequence B sediments are not strongly weathered and do not contain local material derived from physical weathering of the rockshelter wall and ceiling (Table I). The composition of the fine-grained alluvial sediments at Boila indicates that glacial activity had ceased or was much reduced at this time and was no longer supplying large volumes of sediment to the fluvial system. Their composition contrasts markedly to the limestone and till dominated fine matrix within cold stage gravel deposits and the slackwater sediments deposited around the Last Glacial Maximum.

The pollen records from the area indicate that forest expansion was underway at this time in Epirus (Tzedakis, 1993; Turner and Sanchez-Goni, 1997) and, even though it is now well known that the area supported important refugial populations, the paleoclimatic significance of these pollen records is not clear (see Prentice et al., 1992). Anthracological analysis at Boila lends support to the regional palynological record and allows further refinement of our understanding of the development of the local vegetational communities (Ntinou and Kotjabopoulou, 2000; also see Hansen, 2001). Ntinou and Kotjabopoulou (2000) report the analysis of 2692 dispersed charcoal fragments from the Boila sequence; $77 \%$ of these fragments have been identified, representing 31 taxa. The main feature of the record is the sustained forest component throughout the sequence, with birch dominant from ca. 14,500 to 10,000 yr B.P. The Boila charcoal record is not characterized by significant vegetational changes, and nearly half of the taxa identified are present in all samples (Ntinou and Kotjabopoulou, 2000). The dispersed charcoal associated with the finegrained alluvial sediments at Boila points to the existence of a diverse riparian tree community within the immediate vicinity of the site and open conditions in the wider environment within a framework of pioneer woodland expansion dominated by birch. The deposition of the central and upper part of the slackwater sediments coincided with the major phase of Late Upper Paleolithic occupation at Klithi rockshelter where the exploitation of ibex and chamois was the dominant activity. These species require open, treeless habitats on steepland terrains. The charcoal work at Boila is still in progress, and the sediment provenance data may

Table VII. Uncalibrated and calibrated AMS radiocarbon ages from the slackwater sediments at Boila rockshelter. ${ }^{\mathrm{a}}$

\begin{tabular}{ccccc}
\hline Laboratory Code & Radiocarbon Determination & \multicolumn{3}{c}{ Calibrated Date (cal yr B.P.) } \\
\hline OxA-5246 & $13,810 \pm 130$ & 17,150 & $(95.4 \%)$ & 15,950 \\
& & 16,850 & $(68.2 \%)$ & 16,250 \\
Beta 109162 & $13,960 \pm 260$ & 17,550 & $(95.4 \%)$ & 15,950 \\
& & 17,150 & $(68.2 \%)$ & 16,350 \\
Beta 109187 & $14,310 \pm 200$ & 17,850 & $(95.4 \%)$ & 16,450 \\
& & 17,500 & $(68.2 \%)$ & 16,800 \\
\hline
\end{tabular}

a Probabilities for calibrations are shown in parentheses. Calibrations obtained using OxCal version 3.5. 
prove to be important in understanding the origin and taphonomy of the charcoal record (see Hansen, 2001).

The absence of fluvial sediments in the Boila record after ca. 13,800 yr B.P. may indicate that valley floor incision had taken place as a result of large floods events, perhaps associated with a much reduced sediment supply compared with full glacial conditions. Previous work on the alluvial sediments and landforms in the catchment identified the Late Pleistocene Vikos alluvial unit dated by thermoluminescence to $19,600 \pm 3000$ yr B.P. (Lewin et al., 1991; compare calibrated dates in Table VII). This is not an extensive unit, but it records an increase in flysch-derived coarse and fine sediments after the limestone dominated alluvial units (including the basal gravels at Boila) that were deposited during phases of headwater glacial activity (Lewin et al., 1991; Woodward et al., 1992, 1995; Macklin et al., 1997; Hamlin et al., 2000). The lithological composition of the slackwater sediments at Boila accords well with a fluvial system adjusting to a progressive decline in limestonederived glacial sediment inputs during the Lateglacial period as erodible and lowerlying flysch basins, yet to be fully colonized by forest, became the dominant source of fine-grained fluvial sediment. This general pattern of environmental change and shifting sediment sources has also been documented in the sedimentary record in Core Y25 at Klithi that penetrated deep into the preoccupation deposits (see Woodward and Bailey, 2000). The erosion of flysch terrains appears to have been widespread during this period because flysch-derived sediments were also deposited at Klithi at this time, but from more local sources of flysch in the Lower Vikos Gorge (Figure 2) and mainly by colluvial and eolian processes instead of direct fluvial inputs (Woodward and Bailey, 2000).

\section{CONCLUSIONS}

We have employed a multiparameter or composite fingerprinting approach to part of a Lateglacial rockshelter sequence in northwest Greece. During the last cold stage, the sediment load of the Voidomatis River was dominated by sediments derived from glacial erosion of the limestone uplands. The central and upper slackwater sediments at Boila were deposited by a series of large flood events between ca. 14,310 and 13,960 yr B.P. These floods took place during the global cooling associated with Heinrich event 1, although sediment fingerprinting techniques indicate that glacial activity in the Voidomatis basin was no longer supplying large volumes of sediment to the fluvial system at this time. The sediment source estimates for the slackwater sediments at Boila suggest that they result from floods that eroded sediments from the headwater flysch basins. This period coincided with a major phase of Late Upper Paleolithic occupation at Klithi rockshelter.

Although the slackwater deposits are clearly fluvial in origin, the sediment fingerprinting approach can also be used to provide information on the source of rockshelter sediments that have been transported by other mechanisms such as eolian and colluvial processes. It is important to test the results of the fingerprinting approach with independent techniques such as estimates of material abundance 
from thin sections. In combination with micromorphological analyses in particular, this approach offers considerable potential both to improve our understanding of site formation processes and to explicitly integrate rockshelter sediment records within the wider sediment systems of which they are just one small part.

M.G.M. and J.C.W. acknowledge the support of a grant from the UK Natural Environment Research Council (GR9/2916: Catastrophic Flooding and Environmental Change in Mediterranean Mountain Environments). Rob Hamlin was supported by a School of Geography Ph.D. Studentship. We thank IGME, Athens, for permission to undertake geological fieldwork in Epirus, David Appleyard and Linda Gregorash of the School of Geography at Leeds for drawing the diagrams and undertaking particle size analyses, respectively, the School of Earth Sciences at Leeds for providing access to XRF facilities, Simon Robinson (University of Manchester) for the use of his mineral magnetic laboratory, and Claire Sedgewick for assistance with field sampling. The archaeological research program at Boila is financed by the Greek Ministry of Culture and the Psyha Institute. We would also like to thank Paul Goldberg and Philip Owens for reviewing the manuscript.

\section{REFERENCES}

Bailey, G.N. (Ed.) (1997a) Klithi: Palaeolithic settlement and Quaternary landscapes in northwest Greece. Volume 1: Excavation and intra-site analysis at Klithi. Cambridge: McDonald Institute for Archaeological Research.

Bailey, G.N. (1997b). Klithi: A synthesis. In G.N. Bailey (Ed.), Klithi: Palaeolithic settlement and Quaternary landscapes in northwest Greece. Volume 2: Klithi in its local and regional setting. Cambridge (pp. 655-677). Cambridge: McDonald Institute for Archaeological Research.

Bailey, G.N., \& Woodward, J.C. (1997). The Klithi deposits: Sedimentology, stratigraphy and chronology. In G.N. Bailey (Ed.), Klithi: Palaeolithic settlement and Quaternary landscapes in northwest Greece. Volume 1: Excavation and intra-site analysis at Klithi (pp. 61-94). Cambridge: McDonald Institute for Archaeological Research.

Bailey, G.N., Carter, P.L., Gamble, C.S., Higgs, H.P., \& Roubet, C. (1984). Palaeolithic investigations in Epirus: The results of the first season's excavations at Klithi, 1983. Annals of the British School of Archaeology at Athens, 79, 7-22.

Bailey, G.N., Lewin, J., Macklin, M.G., \& Woodward, J.C. (1990). The "Older Fill” of the Voidomatis valley Northwest Greece and its relationship to the Palaeolithic archaeology and glacial history of the region. Journal of Archaeological Science, 17, 145-150.

Bailey, G.N., Turner, C., Woodward, J.C., Macklin, M.G., \& Lewin, J. (1997). The Voidomatis basin: An introduction. In G.N. Bailey (Ed.), Klithi: Palaeolithic settlement and Quaternary landscapes in northwest Greece. Volume 2: Klithi in its local and regional setting (pp. 321-345). Cambridge: McDonald Institute for Archaeological Research.

Baker, V.R., Kochel, R.C., Patton, P.C., \& Pickup, G. (1983). Paleohydrologic analysis of Holocene flood slack-water sediments. In J. Collinson \& J. Lewin (Eds.), Modern and ancient fluvial systems (pp. 229-239), Special Publication No. 6. International Association of Sedimentologists.

Bond, G., et al. (1992). Evidence for massive discharges of icebergs into the North Atlantic during the last glacial period. Nature, 360, 245-249.

Bottrill, L.J., Walling, D.E., \& Leeks, G.J.L. (2000). Using recent overbank deposits to investigate contemporary sediment sources in larger river basins. In I.D.L. Foster (Ed.), Tracers in geomorphology (pp. 369-387). Chichester: Wiley.

Collins, A.L., Walling, D.E., \& Leeks, G.J.L. (1997). Source type ascription for fluvial suspended sediment based on a quantitative composite fingerprinting technique. Catena, 29, 1-27.

Collins, A.L., Walling, D.E., \& Leeks, G.J.L. (1998). Use of composite fingerprints to determine the prov- 


\section{WOODWARD ET AL.}

enance of the contemporary suspended sediment load transported by rivers. Earth Surface Processes and Landforms, 23, 31-52.

Cornwall, I. (1958). Soils for the archaeologist. London: Phoenix House.

Courty, M.-A., Goldberg, P., \& Macphail, R.I. (1991). Soils and micromorphology in archaeology. Cambridge: Cambridge University Press.

Ely, L.L., \& Baker, V.R. (1985). Reconstructing palaeoflood hydrology with slackwater deposits: Verde River, Arizona. Physical Geography, 5, 103-126.

Farrand, W.R. (1975). Sediment analysis of a prehistoric rockshelter: The Abri Pataud. Quaternary Research, 5, 1-26.

Foster, I.D.L., Grew, R., \& Dearing, J.A. (1990). Magnitude and frequency of sediment transport in agricultural catchments: A paired lake-catchment study in Midland England. In J. Boardman, I.D.L. Foster, \& J.A. Dearing (Eds.), Soil erosion on agricultural land (pp. 153-171). Chichester: Wiley.

Fuller, I.C., Macklin, M.G., Lewin, J., Passmore, D.G., \& Wintle, A.G. (1998). River response to highfrequency climate oscillations in southern Europe over the past 200 k.y. Geology, 26, 275-278.

Galanidou, N., Tzedakis, P.C., Lawson, I.T., \& Frogley, M.R. (2000). A revised chronological and palaeoenvironmental framework for the Kastritsa rockshelter, northwest Greece. Antiquity, 74, 349355.

Gamble, C.S. (1997). The animal bones from Klithi. In G.N. Bailey (Ed.), Klithi: Palaeolithic settlement and Quaternary landscapes in northwest Greece. Volume 1: Excavation and intra-site analysis at Klithi (pp. 207-244). Cambridge: McDonald Institute for Archaeological Research.

Goldberg, P. (1992). Micromorphology, soils and archaeological sites. In: V.T. Holliday (Ed.), Soils in archaeology (pp. 145-167). Washington, DC: Smithsonian Institution Press.

Hamlin, R.H.B. (2000). Environmental change and catastrophic flooding in the Voidomatis and Aoos Basins, Northwest Greece, Doctoral dissertation. Leeds, UK: University of Leeds (unpublished).

Hamlin, R.H.B., Woodward, J.C., Black, S., \& Macklin, M.G. (2000). Sediment fingerprinting as a tool for interpreting long-term river activity: The Voidomatis basin, NW Greece. In I.D.L. Foster (Ed.), Tracers in geomorphology (pp. 473-501). Chichester: Wiley.

Hansen, J. (2001). Macroscopic plant remains from Mediterranean caves and rockshelters: Avenues of interpretation. Geoarchaeology: An International Journal, 16, in press.

IGME. (1968). 1:50,000 Geological map of Greece, Doliana sheet. Athens: Institute of Geological and Mineral Exploration.

IGME. (1970). 1:50,000 Geological map of Greece, Tsepelovon sheet. Athens: Institute of Geological and Mineral Exploration.

Karkanas, P. (1999). Lithostratigraphy and micromorphology of Theopetra cave deposits, Thessaly Greece: Some preliminary results. In G.N. Bailey, E. Adam, E. Panagopoulou, C. Perlès, \& K. Zachos (Eds.), The Palaeolithic archaeology of Greece and adjacent areas (pp. 240-251), British School at Athens Studies 3. London: British School at Athens.

Karkanas, P. (2001). Site formation processes in Theopetra cave: A record of climatic change during the Late Pleistocene and early Holocene in Thessaly, Greece. Geoarchaeology: An International Journal, 16(4), 373-399.

Karkanas, P., Kyparissi-Apostolika, N., Bar-Yosef, O., \& Weiner, S. (1999). Mineral assemblages in Theopetra, Greece: A framework for understanding diagenesis in a prehistoric cave. Journal of Archaeological Science, 26, 1171-1180.

Kochel, R.C., \& Baker, V.R. (1988). Paleoflood analysis using slackwater deposits. In V.R. Baker, R.C. Kochel, \& P.C. Patton (Eds.), Flood geomorphology (pp. 357-376). New York: Wiley.

Kotjabopoulou, E., Panagopoulou, E., \& Adam, E. (1997). The Boila rockshelter: A preliminary report. In G.N. Bailey (Ed.), Klithi: Palaeolithic settlement and Quaternary landscapes in northwest Greece, Volume 2: Klithi in its local and regional setting (pp. 427-437). Cambridge: McDonald Institute for Archaeological Research.

Kotjabopoulou, E., Panagopoulou, E., \& Adam, E. (1999). The Boila rockshelter: Further evidence of human activity in the Voidomatis Gorge. In G.N. Bailey, E. Adam, E. Panagopoulou, C. Perlès, \& K. Zachos (Eds.), The Palaeolithic archaeology of Greece and adjacent areas (pp. 197-210), British School at Athens Studies 3. London: British School at Athens. 
Lewin, J., Macklin, M.G., \& Woodward, J.C. (1991). Late Quaternary fluvial sedimentation in the Voidomatis Basin, Epirus, northwest Greece. Quaternary Research, 35, 103-115.

Macklin, M.G., Lewin, J., \& Woodward, J.C. (1997). Quaternary river sedimentary sequences of the Voidomatis Basin. In G.N. Bailey (Ed.), Klithi: Palaeolithic settlement and Quaternary landscapes in northwest Greece, Volume 2: Klithi in its local and regional setting (pp. 347-359). Cambridge: McDonald Institute for Archaeological Research.

Macklin, M.G., Woodward, J.C., \& Lewin, J. (1998). Catastrophic flooding and environmental change in Mediterranean mountain environments, final report to the UK Natural Environment Research Council (NERC). Leeds: School of Geography, University of Leeds (unpublished).

Mandel, R.D., \& Simmons, A.H. (1997). Geoarchaeology of the Akrotiri Aetokremnos rockshelter, southern Cyprus. Geoarchaeology: An International Journal, 12, 567-605.

Ntinou, M., \& Kotjabopoulou, E. (2000). Charcoal analysis in Boila rockshelter: Woodland expansion in Epirus, northwestern Greece, during the Late-glacial. Proceedings of the Second International Meeting on Anthracology, Paris, September 13-16, 2000.

O'Conner, J.E., Ely, L.L., Wohl, E.E., Stevens, L.E., Melis, T.S., Kale, V.S., \& Baker, V.R. (1994). A 4500 year record of large floods on the Colorado River in the Grand Canyon, Arizona. Journal of Geology, 102, 1-9.

Peart, M.R., \& Walling, D.E. (1988). Techniques for establishing suspended sediment sources in two drainage basins in Devon, UK: A comparative assessment. In M.P. Bordas \& D.E. Walling (Eds.), Sediment budgets (pp. 269-279), Publication No. 174. Wallingford, UK: International Association of Hydrological Sciences.

Prentice, I.C., Guiot, J., \& Harrison, S.P. (1992). Mediterranean vegetation, lake levels and palaeoclimate at the Last Glacial Maximum. Nature, 360, 658-660.

Rowan, J.S., Goodwill, P., \& Franks, S.W. (2000). Uncertainty estimation in fingerprinting suspended sediment sources. In I.D.L. Foster (Ed.), Tracers in geomorphology (pp. 279-290). Chichester: Wiley.

Slattery, M.C., Walden, J., \& Burt, T.P. (2000). Use of mineral magnetic measurements to fingerprint suspended sediment sources: Results from a linear mixing model. In I.D.L. Foster (Ed.), Tracers in geomorphology (pp. 309-322). Chichester: Wiley.

Thompson, R., \& Oldfield, F. (1986). Environmental magnetism. London: Allen and Unwin.

Turner, C., \& Sanchez-Goni, M.-F. (1997). Late glacial landscape and vegetation in Epirus. In G.N. Bailey (Ed.), Klithi: Palaeolithic settlement and Quaternary landscapes in northwest Greece, Volume 2: Klithi in its local and regional setting (pp. 559-585). Cambridge: McDonald Institute for Archaeological Research.

Tzedakis, P.C. (1993). Long-term tree populations in northwest Greece through multiple Quaternary climatic cycles. Nature, 364, 437-440.

Verruchi, C., \& Minisale, A. (1995). Multivariate statistical comparison of northern Appenines Palaeozoic sequences: A case study from the formations of Monti Romani (Southern Tuscany-Northern Latium, Italy). Applied Geochemistry, 10, 581-598.

Walling, D.E., \& Woodward, J.C. (1992). Use of radiometric fingerprints to derive information on suspended sediment sources. In J. Bogen, D.E. Walling, \& T. Day (Eds.), Erosion and sediment transport monitoring programmes in river basins (pp. 153-164), Publication No. 210. Wallingford, UK: International Association of Hydrological Sciences.

Walling, D.E., \& Woodward, J.C. (1995). Tracing suspended sediment sources in river basins: A case study of the River Culm, Devon, UK. Marine and Freshwater Research, 46, 327-336.

Walling, D.E., Woodward, J.C., \& Nicholas, A.P. (1993). A multi-parameter approach to fingerprinting suspended sediment source. In N.E. Peters, E. Hoehn, Ch. Leibundgut, N. Tase, \& D.E. Walling (Eds.), Tracers in hydrology (pp. 329-338), Publication No. 215. Wallingford, UK: International Association of Hydrological Sciences.

Woodward, J.C. (1990). Late Quaternary sedimentary environments in the Voidomatis basin, northwest Greece, unpublished doctoral dissertation, University of Cambridge.

Woodward, J.C. (1997a). Late Pleistocene rockshelter sedimentation at Klithi. In G.N. Bailey (Ed.), Klithi: Palaeolithic settlement and Quaternary landscapes in northwest Greece, Volume 2: Klithi in its local and regional setting (pp. 361-376). Cambridge: McDonald Institute for Archaeological Research. 


\section{WOODWARD ET AL.}

Woodward, J.C. (1997b). Late Pleistocene rockshelter sedimentation at Megalakkos. In G.N. Bailey (Ed.), Klithi: Palaeolithic settlement and Quaternary landscapes in northwest Greece, Volume 2: Klithi in its local and regional setting (pp. 377-393). Cambridge: McDonald Institute for Archaeological Research.

Woodward, J.C., \& Bailey, G.N. (2000). Sediment sources and terminal Pleistocene geomorphological processes recorded in rockshelter sequences in Northwest Greece. In I.D.L. Foster (Ed.), Tracers in geomorphology (pp. 521-551). Chichester: Wiley.

Woodward, J.C., \& Goldberg, P. (2001). The sedimentary records in Mediterranean rockshelters and caves: Archives of environmental change. Geoarchaeology: An International Journal, 16, in press.

Woodward, J.C., Lewin, J., \& Macklin, M.G. (1992). Alluvial sediment sources in a glaciated catchment: The Voidomatis basin, northwest Greece. Earth Surface Processes and Landforms, 16, 205-216.

Woodward, J.C., Macklin, M.G., \& Lewin, J. (1994). Pedogenic weathering and relative-age dating of Quaternary alluvial sediments in the Pindus Mountains of northwest Greece. In D.A. Robinson \& R.B.G. Williams (Eds.), Rock weathering and landform evolution (pp. 259-283). Chichester: Wiley.

Woodward, J.C., Lewin, J., \& Macklin, M.G. (1995). Glaciation, river behaviour and the Palaeolithic settlement of upland northwest Greece. In J. Lewin, M.G. Macklin, \& J.C. Woodward (Eds.), Mediterranean Quaternary river environments (pp. 115-129). Rotterdam: Balkema.

Yu, L., \& Oldfield, F. (1989). A multivariate mixing model for identifying sediment sources from magnetic measurements. Quaternary Research, 32, 168-181.

Yu, L., \& Oldfield, F. (1993). Quantitative sediment source ascription using magnetic measurements in a reservoir-catchment system near Nijar, S.E. Spain. Earth Surface Processes and Landforms, 18, 441-454.

Received May 20, 2000

Accepted for publication November 20, 2000 